\title{
Article \\ Heat-Related Mortality in Two Regions of Poland: Focus on Urban and Rural Areas during the Most Severe and Long-Lasting Heatwaves
}

\author{
Dariusz Graczyk ${ }^{1,2, *}$, Iwona Pińskwar ${ }^{1,2}$ and Adam Choryński 1,3 (1) \\ 1 Institute for Agricultural and Forest Environment, Polish Academy of Sciences, Bukowska 19, \\ 60-809 Poznań, Poland; iwona.pinskwar@isrl.poznan.pl (I.P.); adam.chorynski@isrl.poznan.pl (A.C.) \\ 2 Department of Land Improvement, Environmental Development and Spatial Management, \\ Faculty of Environmental Engineering and Mechanical Engineering, Poznan University of Life Sciences, \\ Piatkowska 94E, 60-649 Poznań, Poland \\ 3 Meteorology Laboratory, Department of Construction and Geoengineering, Faculty of Environmental \\ Engineering and Mechanical Engineering, Poznan University of Life Sciences, Piątkowska 94 \\ 60-649 Poznań, Poland \\ * Correspondence: darekgraczyk@wp.pl
}

check for updates

Citation: Graczyk, D.; Pińskwar, I.; Choryński, A. Heat-Related Mortality in Two Regions of Poland: Focus on Urban and Rural Areas during the Most Severe and Long-Lasting Heatwaves. Atmosphere 2022, 13, 390. https: / / doi.org/10.3390/

atmos 13030390

Academic Editors: Agnieszka Krzyżewska, Jens Hesselbjerg Christensen and Zbigniew Ustrnul

Received: 26 January 2022

Accepted: 24 February 2022

Published: 26 February 2022

Publisher's Note: MDPI stays neutral with regard to jurisdictional claims in published maps and institutional affiliations.

Copyright: (c) 2022 by the authors. Licensee MDPI, Basel, Switzerland. This article is an open access article distributed under the terms and conditions of the Creative Commons Attribution (CC BY) license (https:// creativecommons.org/licenses/by/ $4.0 /)$.

\begin{abstract}
The vast majority of studies on heat-related mortality are focused on large cities. The aim of this study is to fill this research gap and to estimate the impact of high temperatures on the risk of death in smaller towns and villages. The results show that increased mortality is not only a problem in large cities. The risk of death, although usually slightly lower than in highly populated areas, may be higher for the age-related risk group. At temperatures above $35{ }^{\circ} \mathrm{C}$, it may exceed 1.3 in smaller towns and even 1.6 in villages. The increase in mortality during five selected heat waves of high intensity and long duration was also studied for two regions of Poland: Małopolska and Wielkopolska. Towns with a population of less than 10,000 in Małopolska region, during the 2006 heatwave, experienced an increase in the number of deaths by as much as $18 \%$. At the same time in the largest city of Małopolska-Kraków, the death toll rose by $4 \%$. This paper also presents some differences between regions in terms of the impact of heat waves: in the lowland region of Wielkopolska, the mortality rate is generally higher than in the upland region of Małopolska.
\end{abstract}

Keywords: heat waves; mortality; Poland

\section{Introduction}

In many regions of the world, one can observe an increase in the frequency, intensity and duration of heatwaves and warm spells [1,2]. Moreover, significant changes in these heatwave parameters in Europe in the last decade are visible. According to Dell-Marta et al. [3], compared to the end of the 19th century, heat waves in western Europe doubled in length and their number almost tripled. A large increase in some indices related to air temperature extremes is presented by HadEX3 data, e.g., a doubling of the number of hot nights in tropical regions of Asia, South America and Africa [4]. Analyses for Central Europe and Poland also show an increasing frequency of indices related to heat waves, such as the number of hot and very hot days in the year and individual summer months [5-8].

Heatwaves have a negative impact on various sectors of the economy. They lead to an increase in the demand for electricity for cooling purposes and disturbances of energy supplies from thermal and nuclear power plants [9]. Looking at the heat wave of 2003 in Europe, one can also conclude that, in combination with droughts, intense and longlasting heat waves also have a large impact on agriculture, leading to losses in crops, but also are dangerous for the environment, i.e., through forest fires, and the authors of [10] estimated the total financial costs of this wave at around USD 13 billion. The worst possible consequence of heat waves is the increase in the number of deaths recorded during them. 
This is especially true when heat waves are particularly intense and prolonged and occur over a large area. In 2003, Western Europe was hit by a heat wave that caused up to 70,000 deaths in 12 countries [11]. If these estimates are correct, then this is the most tragic natural disaster that has occurred in Europe since the 1908 earthquake in Messina. Another severe heatwave occurred in Eastern Europe in 2010 and, according to Munich Re's estimates, caused 56,000 deaths [12]. This heatwave also reached parts of Poland and, according to [13], could cause over 900 additional deaths in the 10 largest Polish cities.

The history of research on the impact of heat on human health and mortality dates back to the first half of the 20th century $[14,15]$. These were the times when the problem of global warming and the associated increase in the frequency of extreme events was not yet noticed. From the very beginning, research focused mainly on large cities which, for example due to the urban heat island effect, are the most vulnerable to this type of threat. It was similar in the case of studies analyzing this subject in Poland and Central Europe, e.g., $[13,16,17]$. One can find very few analyses dealing with extremes, including heat waves, in small towns in Poland [18]. Few studies have compared heat wave mortality in large cities and in rural areas [19]. The authors of this study state that rural areas are affected in a similar way to urban agglomerations. A significant impact on mortality in rural areas during heat waves is also indicated [20]. Moreover, the fact that the 10 largest towns in Poland are inhabited by $17 \%$ of the whole population of Poland, and villages are inhabited by $40 \%$, is another strong motivation to focus on smaller towns. In order to have a bright view of the problem of heat-associated mortality, one has to concentrate also on these places.

There are several papers devoted to the risk groups that are mostly exposed to the dangerous effects of heat waves. They show that both old age and cardiovascular diseases are very serious risk factors, e.g., [21-25].

The aim of this study is to determine whether and to what extent the problem of increased mortality during heat waves occurs in smaller towns and villages in Poland. An additional element is to determine what similarities and differences exist between regions with a similar population but very different in terms of natural conditions. For this purpose, the number of deaths during the summer periods in which particularly unfavorable thermal conditions occurred are analyzed. In the years 1990-2015, heat waves were distinguished by a high length or intensity. These conditions occurred during the summer periods of 1992, 1994, 2006, 2010, 2015.

\section{Materials and Methods}

\subsection{Study Location}

The two study regions are inhabited by a comparable number of people, and during the most intense heat waves, there were similar anomalies of the maximum daily air temperature. However, these regions differ significantly in the case of size of the area and, as a consequence, population density. An important difference is also the landform and elevation above sea level. A large part of the Małopolska region is located higher than $400 \mathrm{~m}$ above sea level (m.a.s.l) and its southern frontiers are mountainous areas. The greater part of the Wielkopolska region is lowlands with an average elevation of 100 m.a.s.l. This has an impact on meteorological conditions and therefore also affects mortality during heat waves. Selected information about the researched regions is presented in Table 1 and their location together with their altitude above sea level is shown in Figure 1. 
Table 1. Comparison of selected parameters for Wielkopolska and Małopolska Regions.

\begin{tabular}{ccc}
\hline Parameter & Wielkopolska Region & Małopolska Region \\
\hline Population (millions) & 3.485 & 3.386 \\
Area & $29,826 \mathrm{~km}^{2}$ & $15,182 \mathrm{~km}^{2}$ \\
Population density & 116 people per $\mathrm{km}^{2}$ & 222 people per $\mathrm{km}^{2}$ \\
Urbanization rate & $55.2 \%$ & $49.4 \%$ \\
The average temperature of July & $19.6^{\circ} \mathrm{C}$ Poznań & $19.6^{\circ} \mathrm{C}$ Kraków \\
(1991-2020) & $19.3^{\circ} \mathrm{C}$ Poznań & $19.2^{\circ} \mathrm{C}$ Kraków \\
The average temperature of August & 9.2 days Poznań & 10.8 days Tarnów \\
Number of days with Tmax $>30^{\circ} \mathrm{C}$ in & &
\end{tabular}

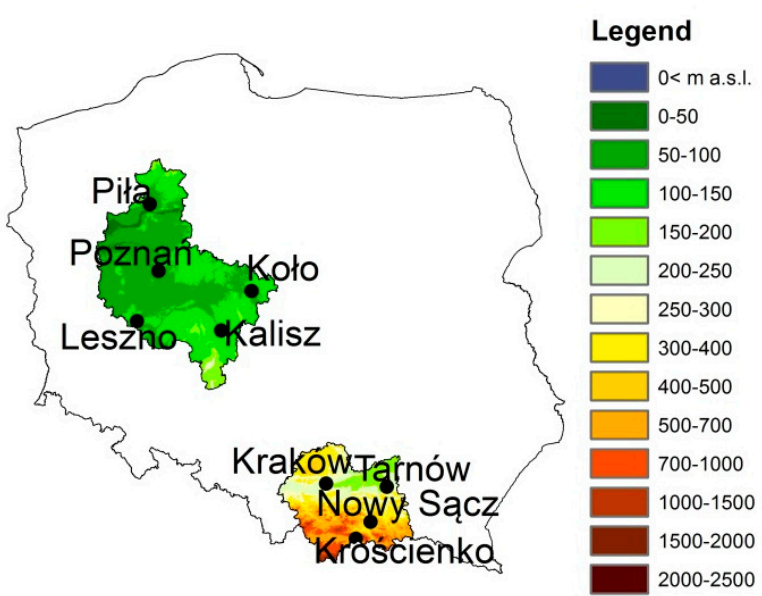

Figure 1. Location and topography of the analyzed regions.

\subsection{Meteorological Data}

Data from nine meteorological stations for 1961-2020 were provided by the Institute of Meteorology and Water Management-State Research Institute [26]. The datasets are of good quality and do not contain any gaps in the daily temperature series. They include daily values of minimum and maximum air temperatures. Temperature anomalies were calculated from average values for two periods: 1961-1990 and 1991-2020.

Many different predictors have been used to determine the relationship between atmospheric conditions and increased mortality. The research by Bartlett et al. [27] did not confirm that any of the methods and measures of temperature were clearly better than the others. Hence, the focus on maximum and minimum temperatures in this work should secure sufficient accuracy of the analyses.

\subsection{Mortality Data}

Daily mortality data for two Polish regions have been acquired from the General Statistical Office of Poland. The database contains information on deaths in Poland for every day in the period of 1989-2016. It includes information on age of the deceased persons and the cause of death, according to the International Classification of Diseases (ICD). Data for 1989-2000 were organized according to the ninth revision of the international classification (ICD9) and data after 2000 were coded according to the tenth revision (ICD10). All deaths due to natural causes: ICD-9 from 1 to 799; ICD-10 groups from A to D, as well as deaths of cardiovascular diseases (CVD), ICD-9 from 390 to 459, ICD-10 group I, were subject to analysis. Age over 65 was also analyzed as a risk factor. 


\subsection{Analysis of the Relationship between Temperature and the Risk of Death in Towns with Different Population Sizes and Villages}

In this work we use the package dlnm within the statistical environment $\mathrm{R}$ [28]. We apply DLNMs (the Distributed Lag Non-Linear Models) to investigate the effect of maximum temperature on overall mortality, mortality among people with cardiovascular diseases and people at the age of 65 years or older. Time series were analyzed for local communities with different population sizes during two periods 1989-1998 and 2001-2016 for Małopolska and Wielkopolska regions. The separation of these 2 periods from the available time series of data on deaths resulted from concerns about the homogeneity of the data for 1999 and 2000 caused by the reform of the administrative division of the country. Most of the analyses described in the paper used data from the years 2001-2016. The data from before the administrative reform were used to assess the differences between the initial period of socio-economic transformation in Poland after the fall of communism and the present ones. Since the early 1990s, there has been an increase in life expectancy and better prevention and treatment of heart diseases [29]. This may have an influence on the results obtained.

Mortality data for local communities were assigned to the nine meteorological stations (five in Wielkopolska and four in Małopolska) for the warm season from June to the end of September. The analyses were based on the cross-basis matrix, which then were fitted through a generalized linear model with quasi-Poisson family, with the following choices regarding the control of confounders: splines of time with 6 degrees of freedom (df), indicator variables for day of the week and day of the year and lag period of 2 . The internal knots were placed by default at equally spaced quantiles, while the boundary knots were located at the range of the observed values. Reference temperature was set to $21^{\circ} \mathrm{C}$ to estimate relative risk (RR) of mortality.

\subsection{Calculations of the Relative Risk of Death for Selected Heat Waves}

A heat wave (sub-wave) is defined as a period of at least 3 consecutive days with a daily maximum temperature above $30{ }^{\circ} \mathrm{C}$. In the case of the longest sub-waves, a 2-day temperature drop below $30^{\circ} \mathrm{C}$ does not interrupt the wave if there is increased mortality.

In order to estimate the impact of heat waves during selected summer periods on the increase in the risk of death from others in which the thermal conditions were neutral for health, a time series of the daily number of deaths should be created for summer periods in which there were no heat waves. The best series would be over as many years as possible. Due to a lack of data or socio-economic or demographic factors, it is not always possible to use long series. The authors of other papers have used reference series composed of data covering a different number of years. It may be, for example, the 5 preceding years [30], but also a much shorter period containing only 1 previous year [31]. It also happens that both the years preceding and following the analyzed heat wave are used for comparisons [32].

In this work, to create the time series, data from 6 years as close as possible to the analyzed heat waves were used, which at the same time met the condition of the absence of an intense and long-lasting heat wave. Where possible, data from the three preceding and three subsequent years were used. The obtained time series of mortality were then combined with the temperature course and the periods of increase in the number of deaths during heat waves were determined.

In order to obtain results that will not be delayed in deaths related to the so-called harvesting effect is sometimes considered also for a longer period of time after the heat waves have subsided, e.g., a 60-day period [30]

This study also analyzed the longer period of time between the first heat wave and 30 days after the last heat wave in a given year.

In authors opinion, the second, longer period shows the actual, more uninfluenced result of mortality increase related to a heat wave, eliminating the effects of shifted mortality, like lag or harvesting effect. 
The explanation of the process of determining the periods of increased temperature and the related increase in the number of deaths is presented in Figure 2.

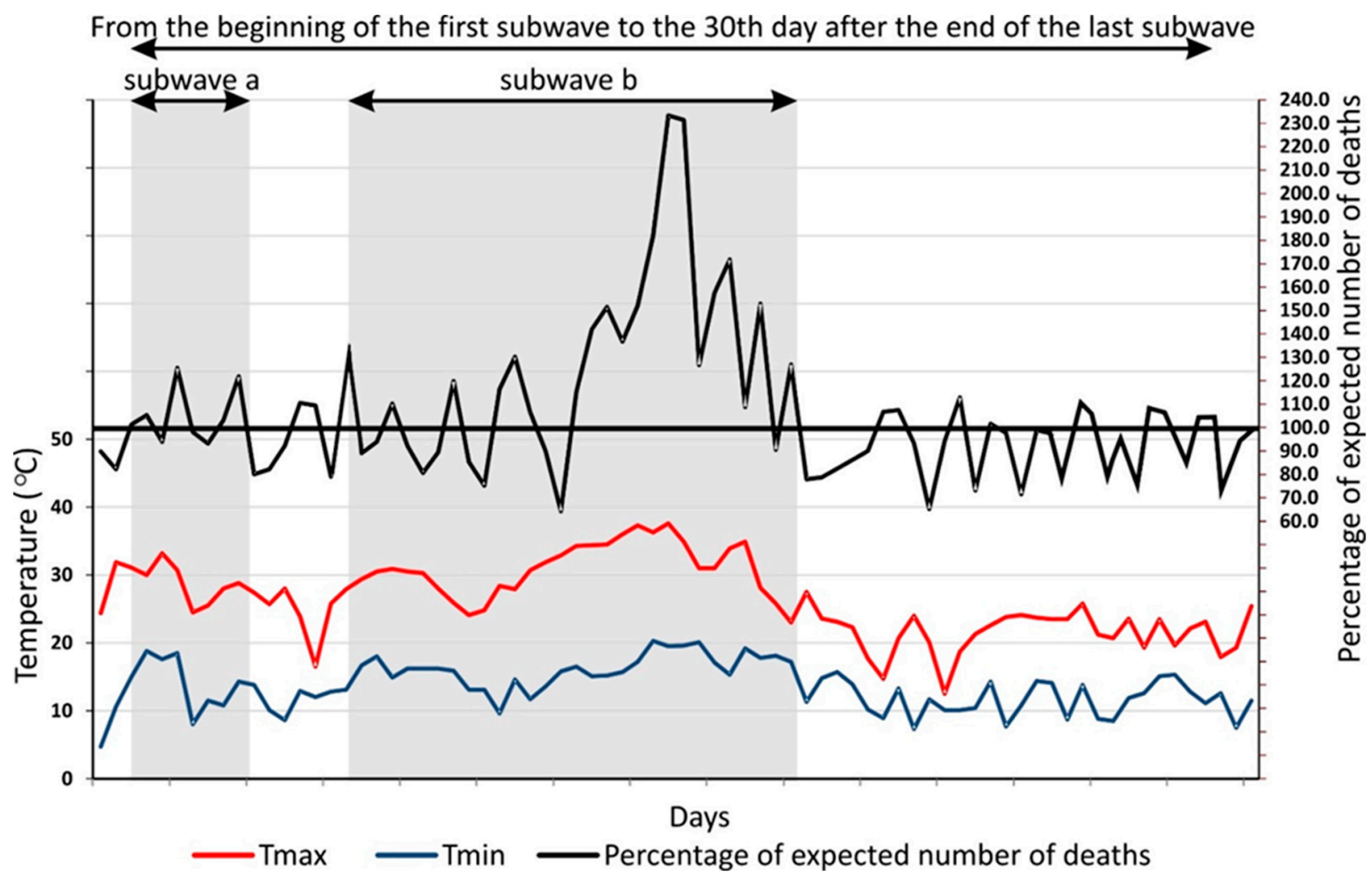

Figure 2. Illustration of the process of determination of time intervals with elevated mortality, related to the occurrence of high values of the air temperature.

To determine the statistical significance of the mortality changes, the $90 \%$ confidence interval (CI) was calculated using the Student's t-test taking into account the standard deviation and sample size.

\section{Results}

\subsection{Thermal Conditions during Selected Heat Waves}

During the summer periods selected for the analysis, only in Wielkopolska in 1992 were absolute records of air temperature broken (Kalisz $38^{\circ} \mathrm{C}$ and Leszno $37.8^{\circ} \mathrm{C}$ ). However, in both regions, there were very high 7- and 14-day anomalies of the maximum daily air temperature (Figure 3). There is also a clearly visible difference between the values of the 7-day and 14-day Tmax anomaly depending on the reference period we take into account. If these are the years 1961-1990, i.e., the period before the analyzed extremely hot years, the 7-day Tmax anomaly exceeds $11^{\circ} \mathrm{C}$ at all weather stations in Wielkopolska, and in Piła it is even $12{ }^{\circ} \mathrm{C}$. In Małopolska, the hottest year for this index was 1992, when the anomaly was around $11^{\circ} \mathrm{C}$ at all the analyzed stations. A slightly lower anomaly, although still close to $11{ }^{\circ} \mathrm{C}$, occurred in Małopolska in 2015. Additionally, the 14-day anomaly calculated in relation to the period 1991-2020 had high values in both regions. In Wielkopolska, the year 1994 stood out again, when at all stations the maximum temperature during the next 14 days was on average $9^{\circ} \mathrm{C}$ or higher more than the average for the years 1961-1990. In Małopolska in the same year, the anomaly for Nowy Sacz also exceeded $9{ }^{\circ} \mathrm{C}$. If the reference period were the years 1991-2020, both the 7- and 14-day anomalies would be lower by even more than $2{ }^{\circ} \mathrm{C}$ degrees. This proves how extraordinary this period was in terms of extreme heat compared to the previous one. 


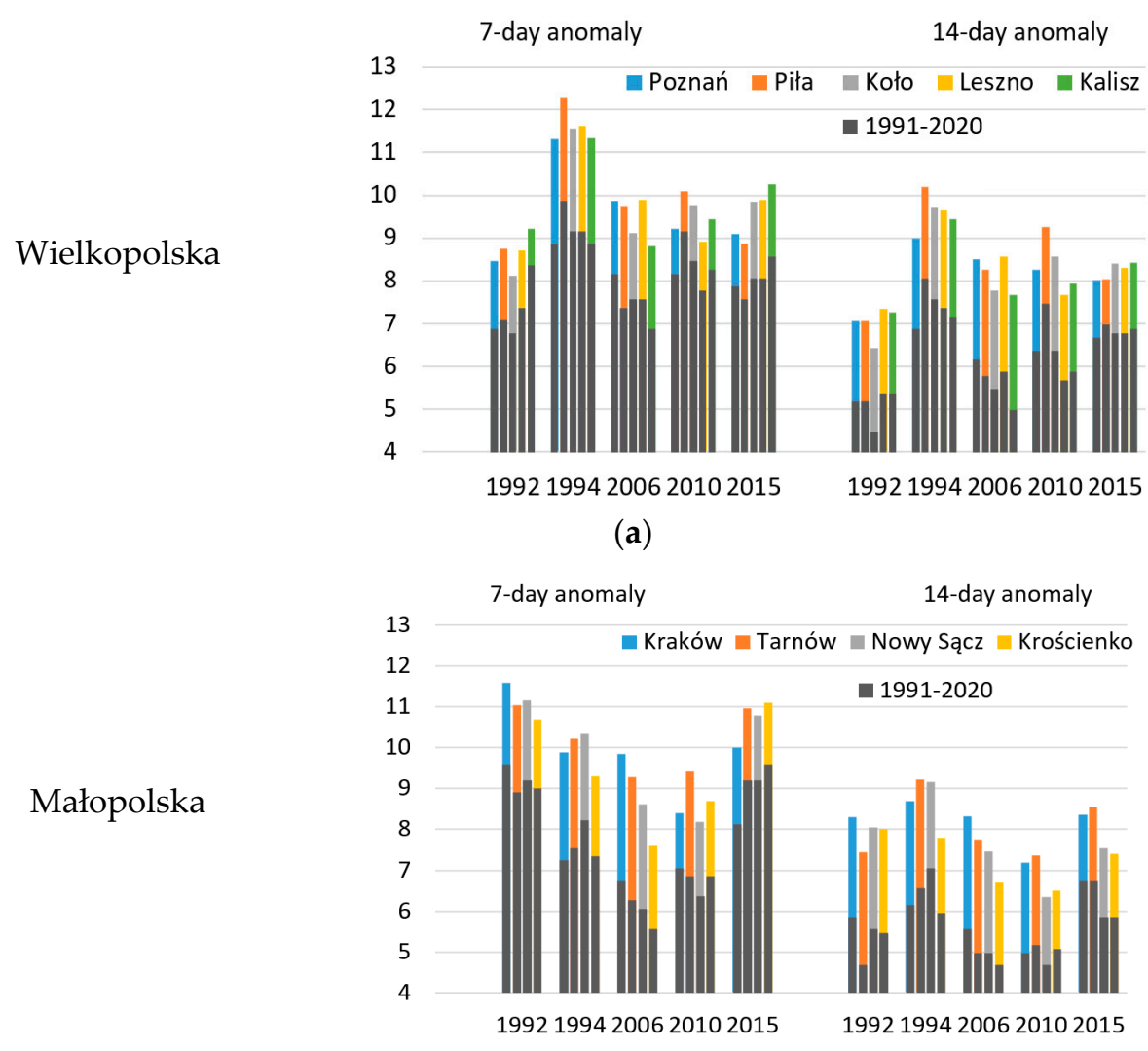

(b)

Figure 3. The highest 7-day and 14-day anomalies of the daily maximum temperature during the hottest summers compared with two reference period: 1961-1990 (colored bars) and 1991-2020 (dark grey bars) in selected stations: (a) Wielkopolska; (b) Małopolska.

\subsection{Relation between the Relative Risk of Death and the Maximum Daily Air Temperature}

\subsubsection{Increased Relative Risk of Death in the Regions Depending on the Population Size}

Figures 4-9 show how relative risk (RR) changed for different Tmax values in cities of different sizes in both analyzed regions. The analyses carried out concerned all deaths in the years 2001-2016 without division into age-related risk groups and the cause of death.

In the largest cities of both regions (Kraków, Poznań), with high Tmax values, one can observe a clear increase in the risk of death (Figure 4). At the maximum daily air temperature of about $30^{\circ} \mathrm{C}$, it is very similar and does not exceed 1.2. At temperatures exceeding $35^{\circ} \mathrm{C}$, the risk of death is higher in Poznań, closing to 1.6, while in Kraków, it is slightly lower than 1.5 .

In towns with a population between 50 and 150 thousand in Wielkopolska, when the Tmax close to $30^{\circ} \mathrm{C}$, RR is similar to that observed in Poznań and does not exceed 1.2, but at temperatures well above $35^{\circ} \mathrm{C}$ reaches almost 1.6. In Małopolska, the risk of death is only slightly increased at Tmax around $30^{\circ} \mathrm{C}$. Nevertheless, at temperatures well above 35 ${ }^{\circ} \mathrm{C}$, it is higher than in the largest city of the region (Kraków) and the RR is 1.5 (Figure 5).

In towns with a population between 25 and 50 thousand (Figure 6), the RR at temperatures close to $30^{\circ} \mathrm{C}$ is similar in both regions (RR 1.1). It is similar also in the case of the highest recorded temperatures, where the RR for both regions exceeds 1.3.

In towns with a population of between 10 and 25 thousand inhabitants, the increase in $\mathrm{RR}$ is clearly higher in Wielkopolska than in Małopolska. In Wielkopolska, a statistically significant increase in RR exceeding 1.1 is observed at temperatures close to $30{ }^{\circ} \mathrm{C}$. At temperatures significantly above $35^{\circ} \mathrm{C}$, the RR becomes 1.4. In Małopolska, a slight (RR > 1.1) but statistically significant increase is observed for Tmax exceeding $32{ }^{\circ} \mathrm{C}$. For temperatures exceeding $35^{\circ} \mathrm{C}$, the RR rises above the value of 1.2 (Figure 7). 


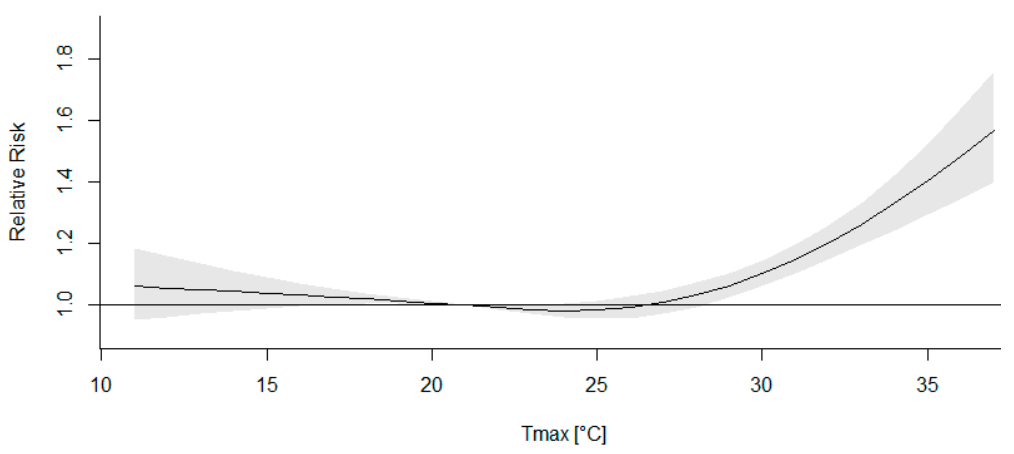

(a)

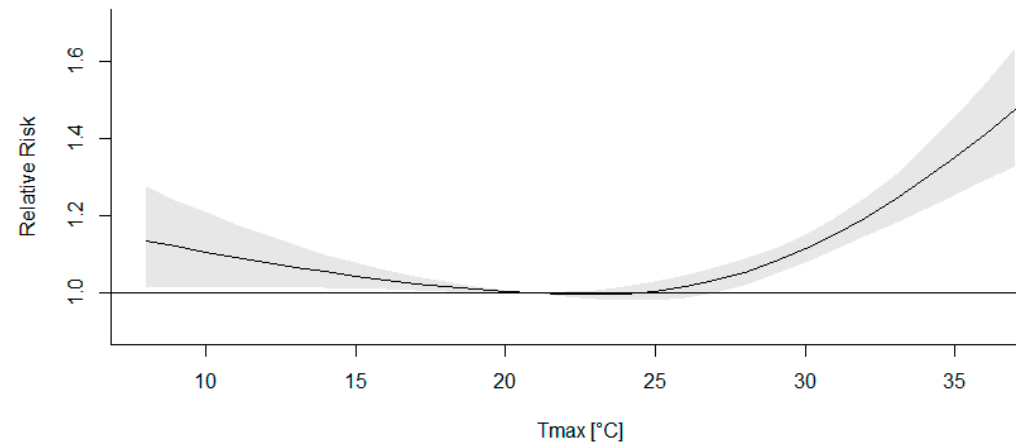

(b)

Figure 4. Relation between daily maximum temperature and relative mortality risk (all non-accidental causes) in warm months (June-September) during 2001-2016 for: (a) Poznań; (b) Kraków.

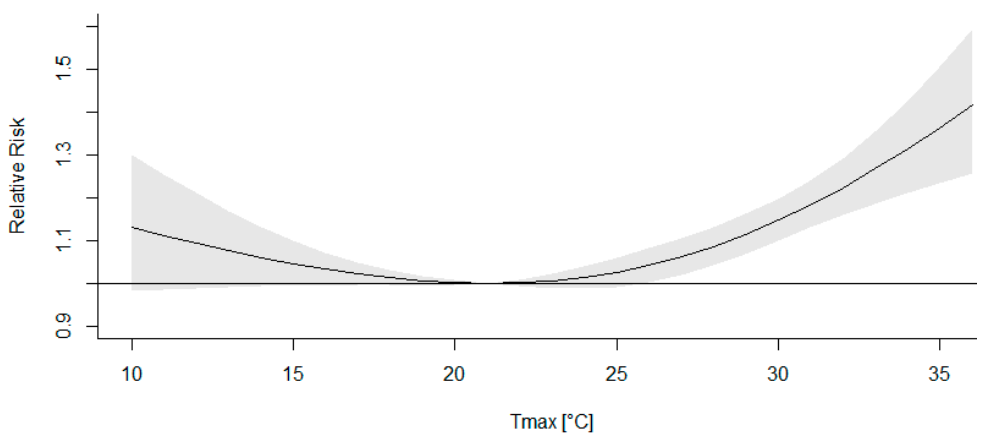

(a)

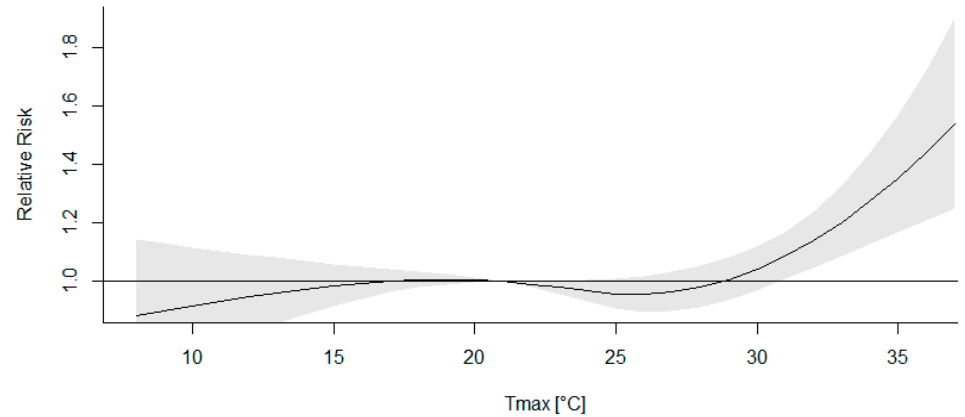

(b)

Figure 5. Relation between daily maximum temperature and relative mortality risk (all non-accidental causes) in warm months (June-September) for towns with population of 50-150 thousand during 2001-2016: (a) Wielkopolska; (b) Małopolska. 


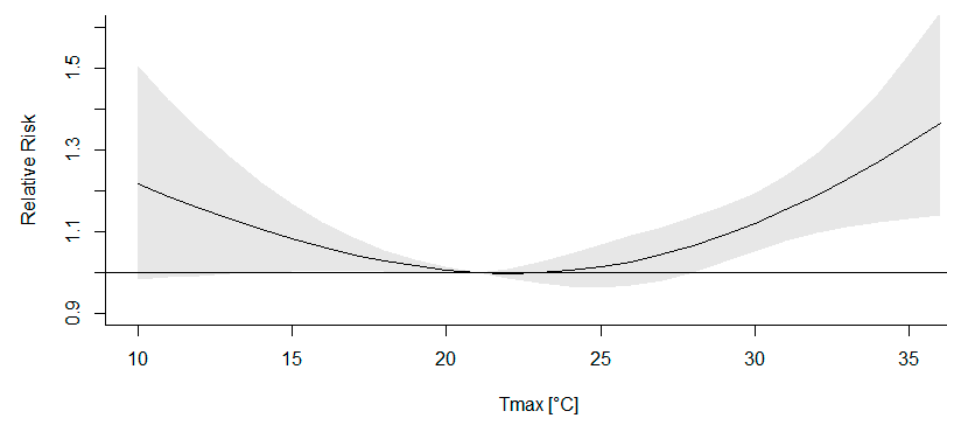

(a)

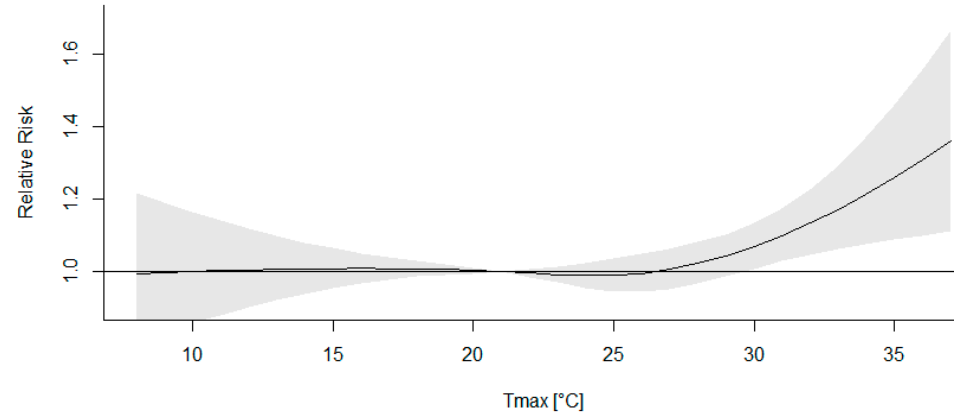

(b)

Figure 6. Relation between daily maximum temperature and relative mortality risk (all non-accidental causes) in warm months (June-September) for towns with population of 25-50 thousand during 2001-2016: (a) Wielkopolska; (b) Małopolska.

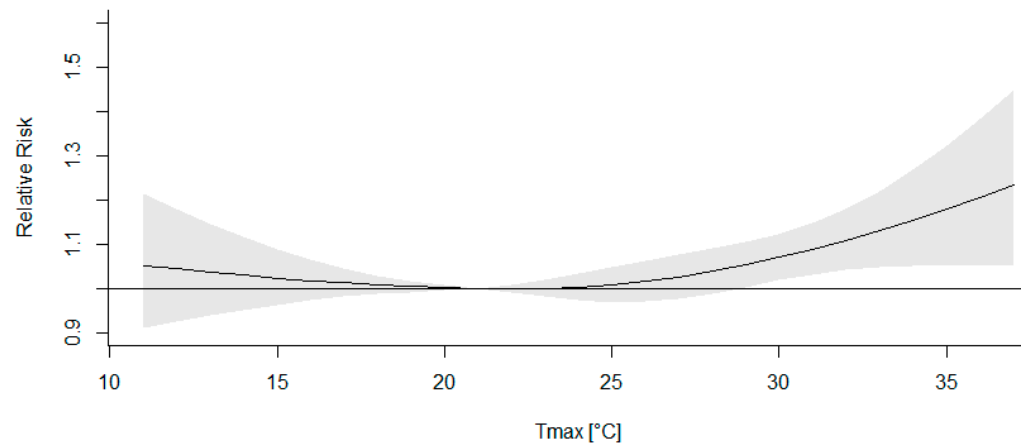

(a)

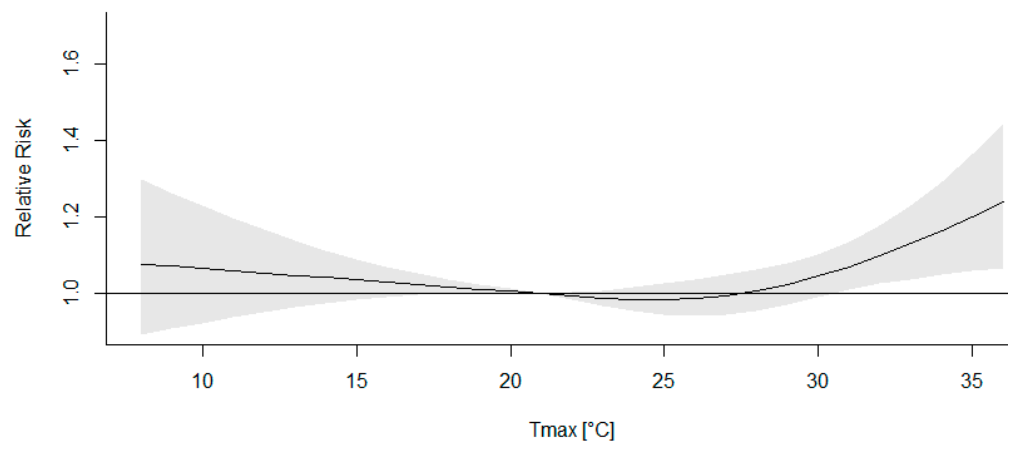

(b)

Figure 7. Relation between daily maximum temperature and relative mortality risk (all non-accidental causes) in warm months (June-September) for towns with a population of 10-25 thousand during 2001-2016: (a) Wielkopolska; (b) Małopolska. 
In towns with less than 10 thousand inhabitants in Wielkopolska (Figure 8a), an increase in the risk of death exceeding 1.1 is recorded at $\operatorname{Tmax}>30^{\circ} \mathrm{C}$. At temperatures exceeding $35^{\circ} \mathrm{C}$, the increase in $\mathrm{RR}$ is already very noticeable and reaches 1.4 . We can observe slightly lower values of RR in small towns of Małopolska. RR at temperatures above $35^{\circ} \mathrm{C}$ does not exceed 1.3 (Figure 8 b).

In rural areas of both regions (Figure 9), a slight increase in the risk of death ( $R R \sim 1.1)$ already at temperatures of around $30^{\circ} \mathrm{C}$ is observed. At temperatures above $35^{\circ} \mathrm{C}$, the RR is already high: 1.4 in Małopolska and 1.5 in Wielkopolska.

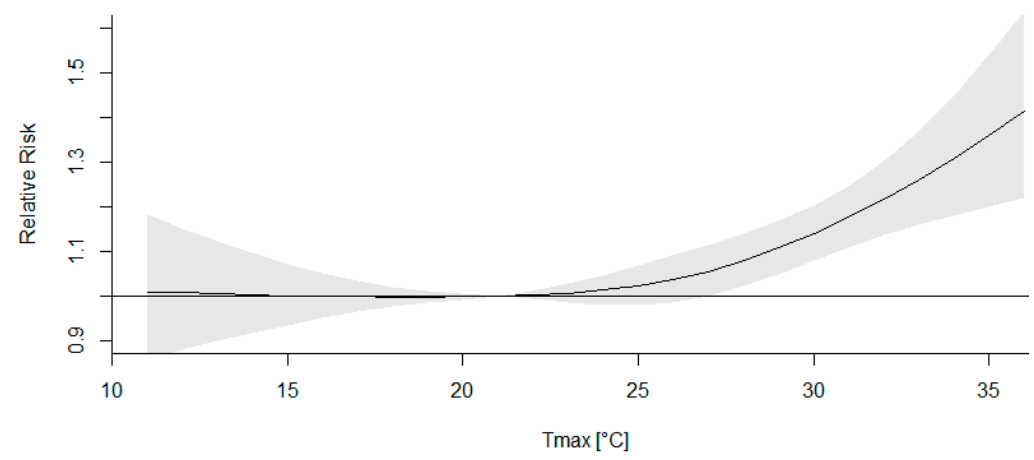

(a)

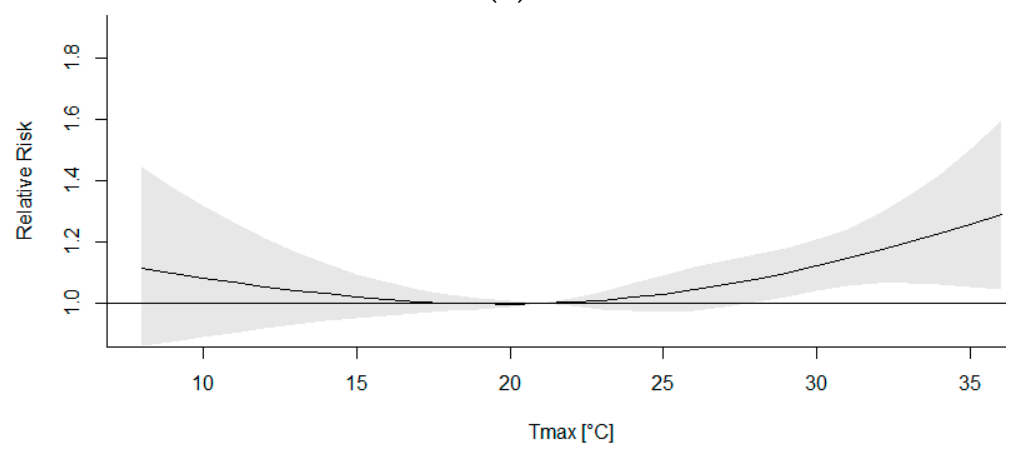

(b)

Figure 8. Relation between daily maximum temperature and relative mortality risk (all non-accidental causes) in warm months (June-September) for towns with population of below 10 thousand during 2001-2016: (a) Wielkopolska; (b) Małopolska.

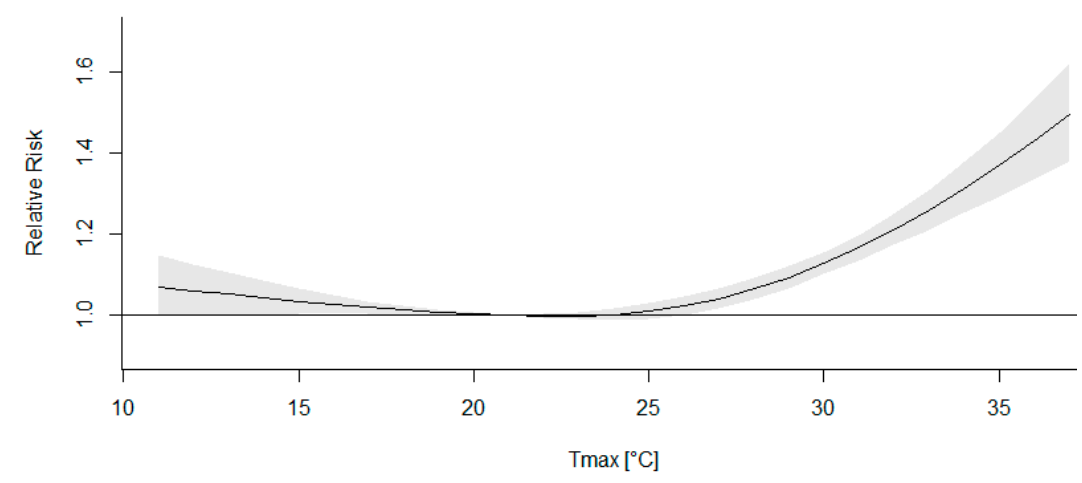

(a)

Figure 9. Cont. 


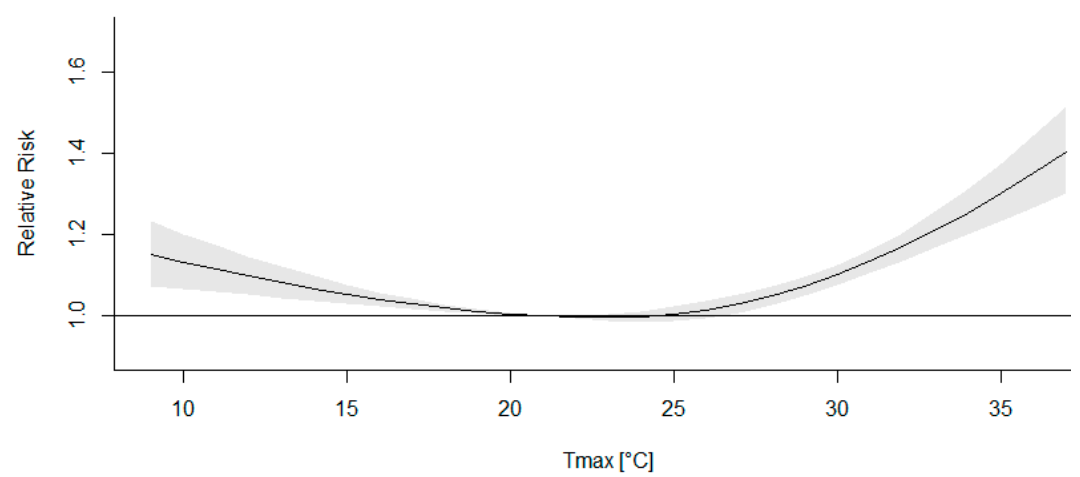

(b)

Figure 9. Relation between daily maximum temperature and relative mortality risk (all nonaccidental causes) in warm months (June-September) for villages during 2001-2016: (a) Wielkopolska; (b) Małopolska.

\subsubsection{Relative Risk of Death in the Age Group 65+ and Caused by Cardiovascular Diseases}

In Wielkopolska, a significant (even exceeding 1.6) increase in the risk of death along age group 65+ with an increase in Tmax is observed both in the largest city of the region (Poznań) and in towns below 10 thousand inhabitants (Figure 10). In other analyzed towns and villages, the increase in RR is slightly lower but still statistically significant (see Supplementary Materials).

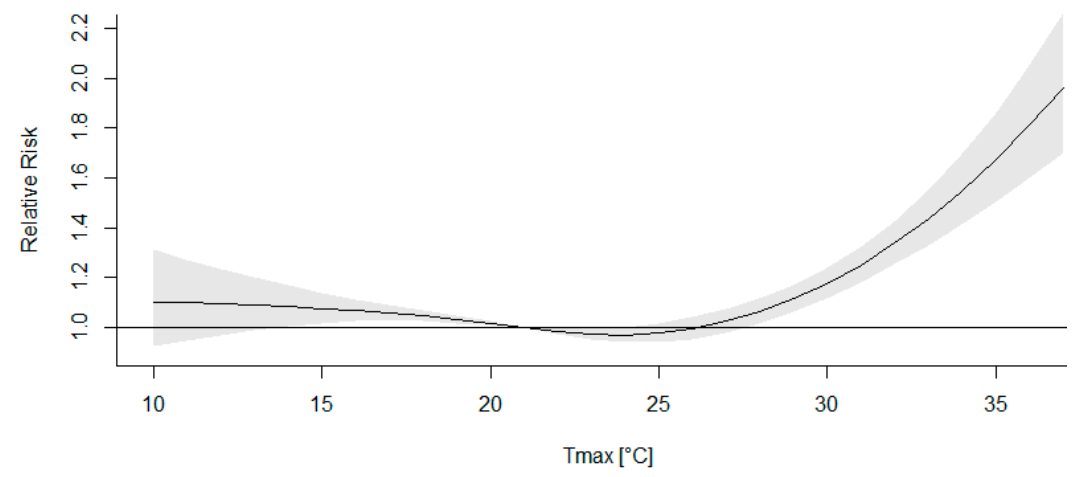

(a)

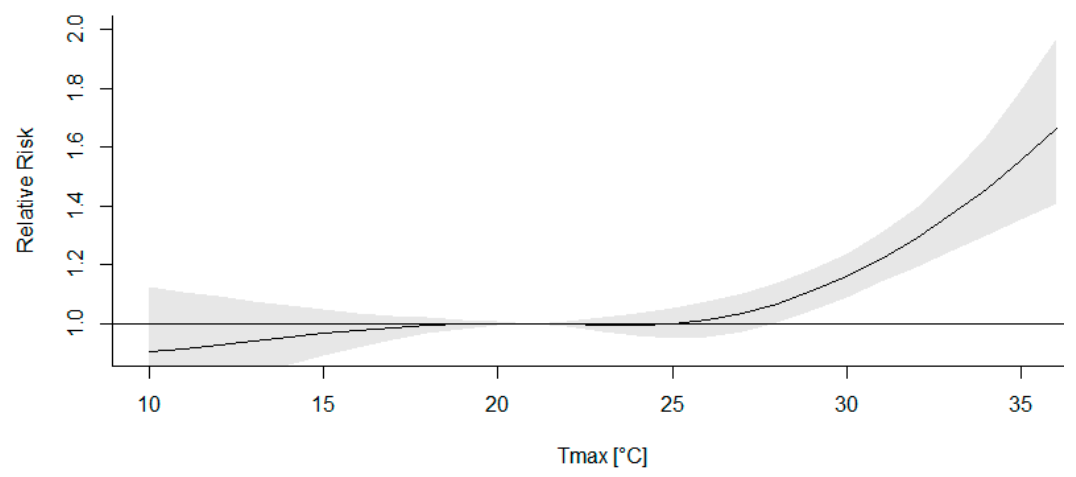

(b)

Figure 10. Relation between daily maximum temperature and relative mortality risk (age 65 and older) in warm months (June-September) during 2001-2016: (a) Poznań; (b) towns with population of below 10 thousand in Wielkopolska. 
In Małopolska, the increase in the risk of death with temperature increase for this risk group is generally lower: 1.5 in Kraków and 1.4 for villages in this region (Figure 11). For the other town size ranges, the increase in RR is usually much lower and often statistically insignificant (see Supplementary Materials).

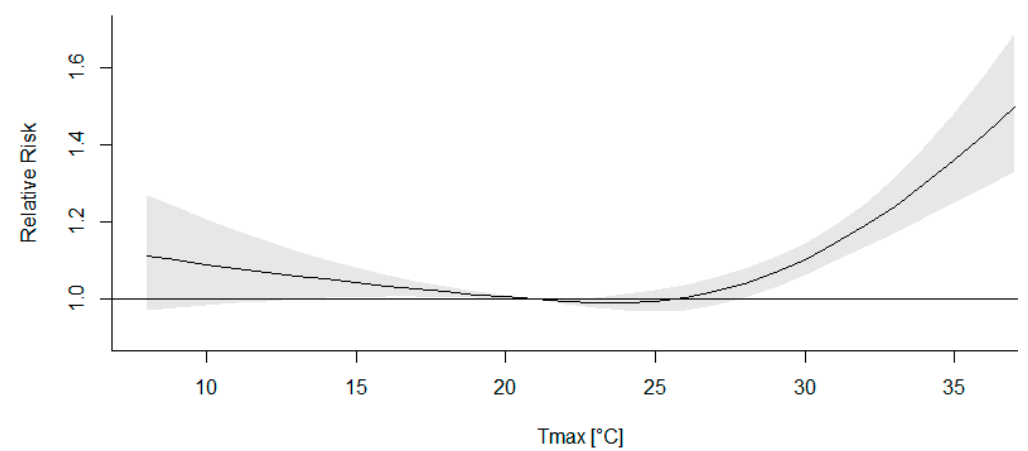

(a)

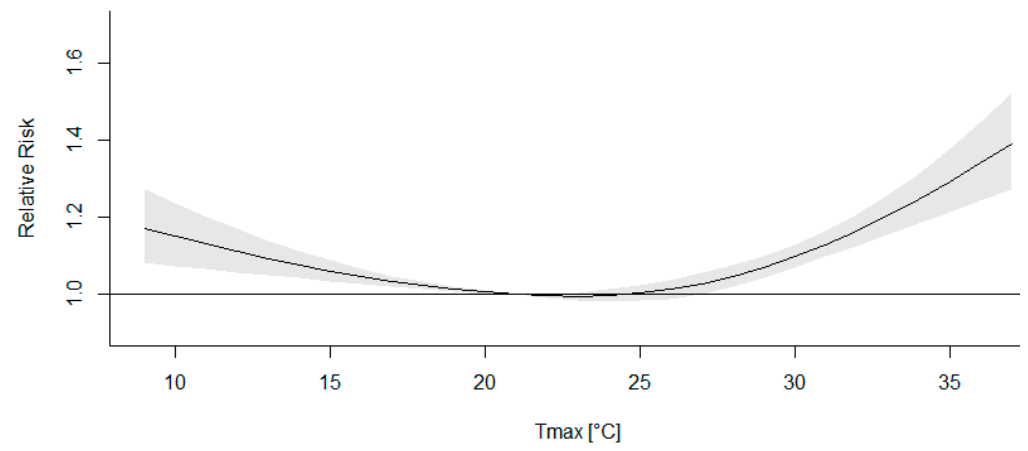

(b)

Figure 11. Relation between daily maximum temperature and relative mortality risk (age 65 and older) in warm months (June-September) during 2001-2016: (a) Kraków; (b) villages in Małopolska.

For the largest cities in both regions, the risk of cardiovascular disease-related death increases already at a Tmax of around $30{ }^{\circ} \mathrm{C}(\mathrm{RR}>1.1)$. With Tmax $>35^{\circ} \mathrm{C}$ in Kraków, the risk of death exceeds 1.5, and in Poznań is slightly below 1.6. We can also observe similar results for smaller towns of the Małopolska region (Figure 12). All the results are presented in the Supplementary Materials (Figures S1-S18).

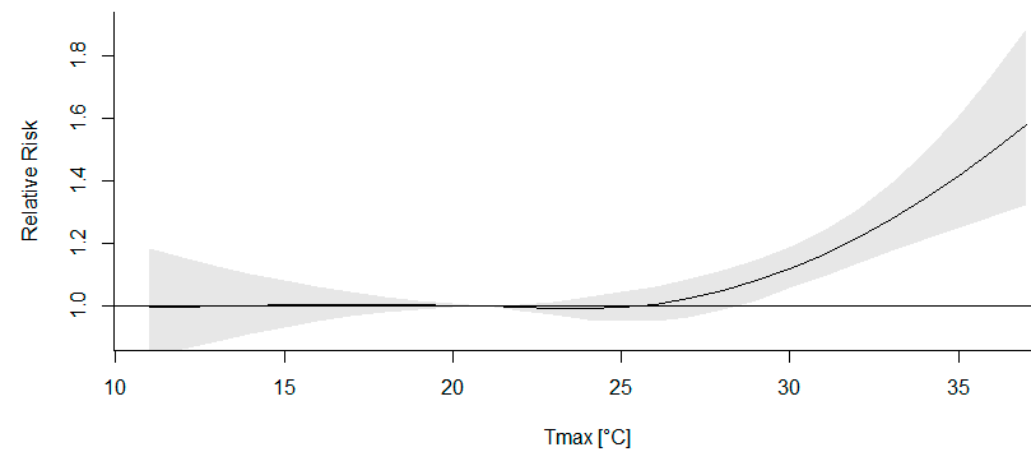

(a)

Figure 12. Cont. 


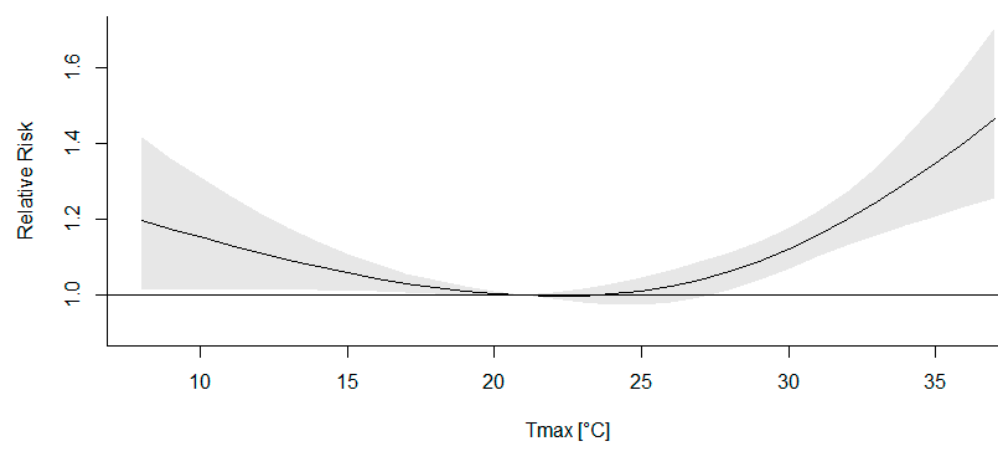

(b)

Figure 12. Relation between daily maximum temperature and relative mortality risk (cardiovascular diseases) in warm months (June-September) during 2001-2016: (a) Kraków; (b) villages in Małopolska.

\subsubsection{Differences between Analyzed Periods: 1989-1998 and 2001-2016}

In Wielkopolska, regardless of whether we consider all deaths or a risk group related to age or cardiovascular disease, a greater or lesser decrease in RR is usually observed in the period 2001-2016 compared to the previous period 1989-1998. It is particularly noticeable in the case of towns with a population of 25-50 thousand and deaths caused by cardiovascular diseases, where in the earlier period, with temperatures significantly above $35^{\circ} \mathrm{C}$, it reached 2.0, while in the later period, the RR for the highest temperatures was around 1.2, and in most cases the results were not statistically significant (Figure 13).

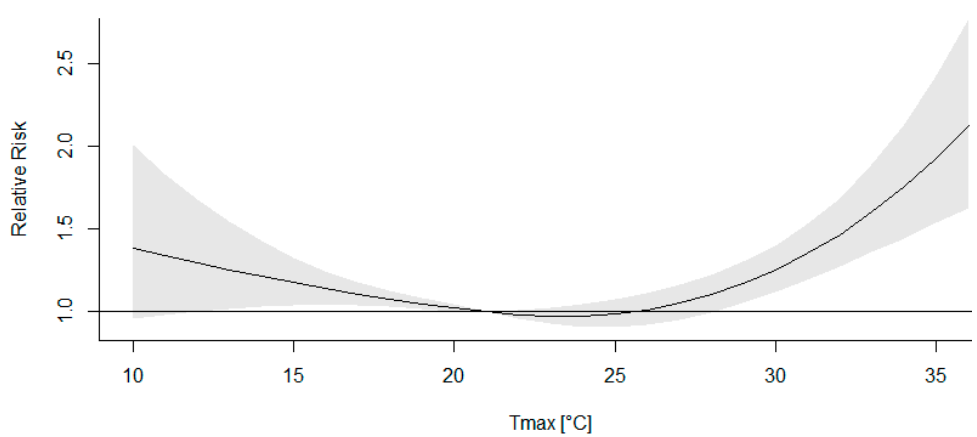

(a)

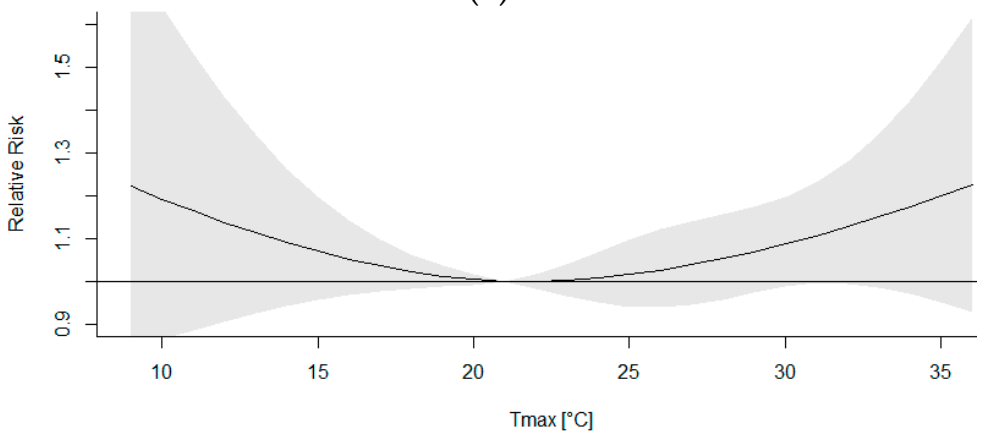

(b)

Figure 13. Relation between daily maximum temperature and relative mortality risk (cardiovascular diseases) in warm months (June-September) for towns with populations of 10-25 thousand in Wielkopolska: (a) 1989-1998; (b) 2001-2016.

For towns with a population of less than 10 thousand and villages, the differences between the periods are smaller. In the case of deaths related to cardiovascular diseases in rural areas, even a slight increase in RR is visible in 2001-2016 (Figure 14). 


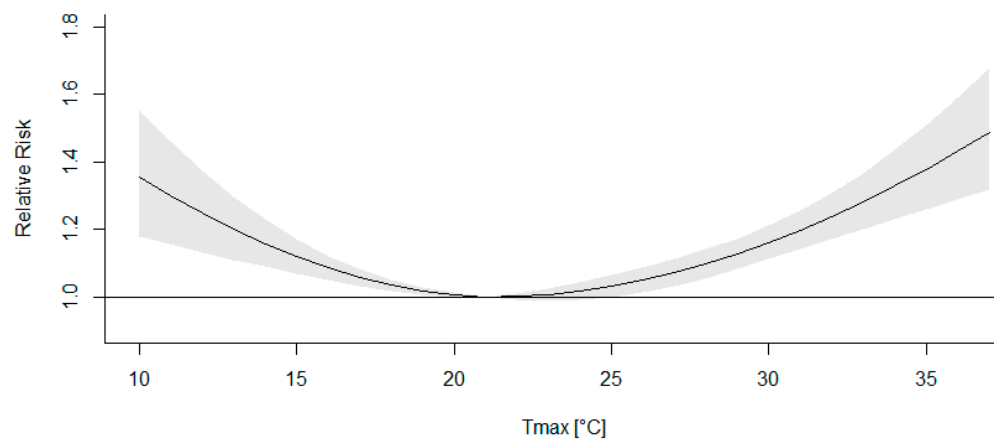

(a)

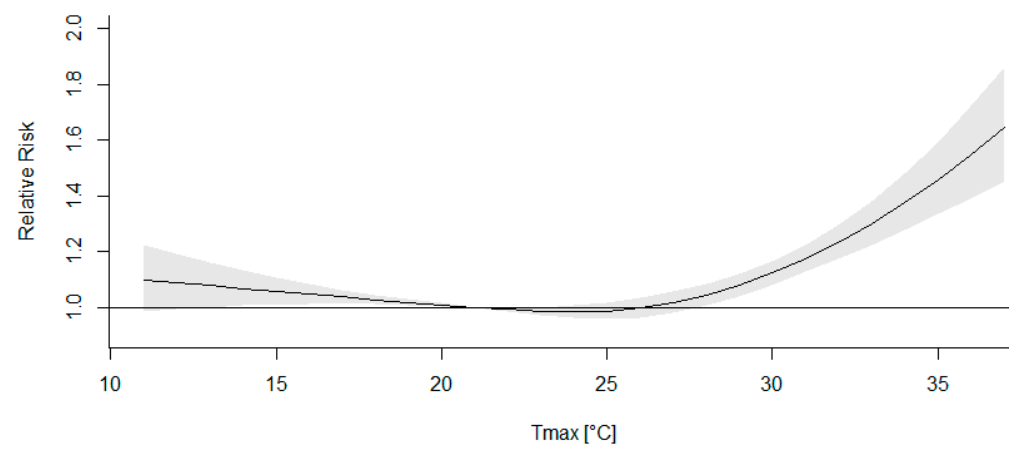

(b)

Figure 14. Relation between daily maximum temperature and relative mortality risk (cardiovascular diseases) in warm months (June-September) for villages: (a) Wielkopolska 1989-1998; (b) Wielkopolska 2001-2016.

In Małopolska, the results depend on the analyzed sub-population and the size of the town. In the largest towns of this region ( $>50$ thousand inhabitants), the later period (2001-2016) is usually characterized by a greater increase in RR. In towns with a population of 25-50 thousand inhabitants, the increase in RR for high values of Tmax was greater in the period 1989-1998, e.g., Figure 15. The above-mentioned cases and other cases that were not referred to in the text are included in Supplementary Materials.

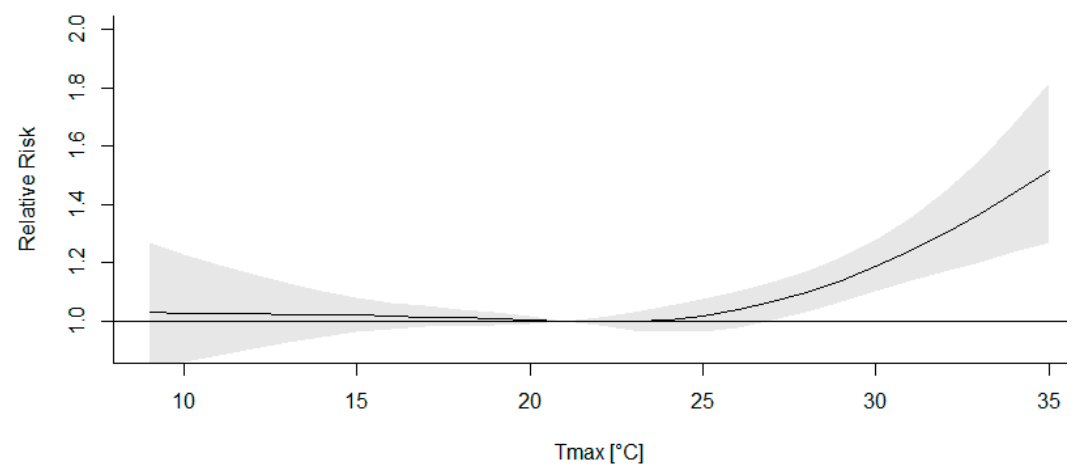

(a)

Figure 15. Cont. 


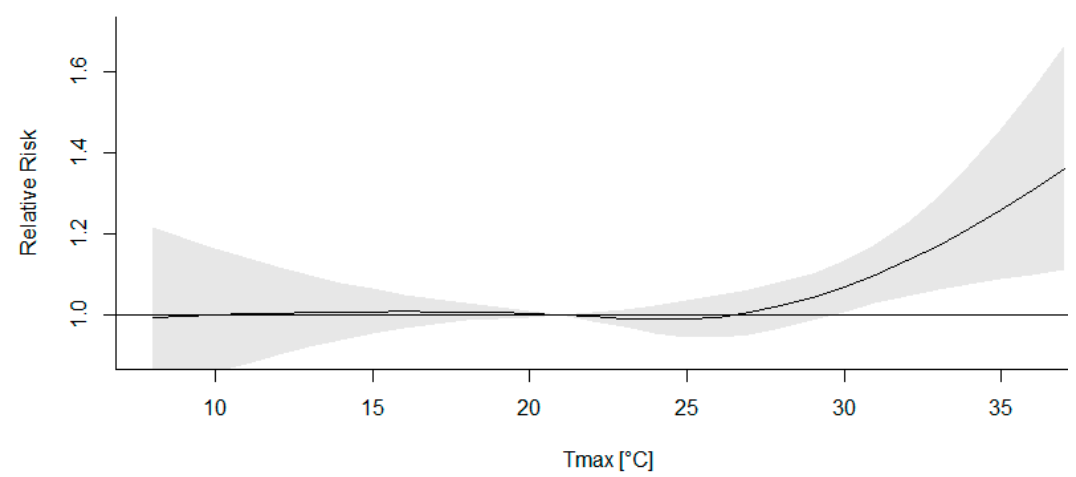

(b)

Figure 15. Relation between daily maximum temperature and relative mortality risk (cardiovascular diseases) in warm months (June-September) for towns with populations of 10-25 thousand: (a) Małopolska 1989-1998; (b) Małopolska 2001-2016.

\subsection{Analysis of Changes in the Risk of Death during Selected Heat Waves 3.3.1. Natural Mortality in the Entire Population}

During each of the studied summer periods, the authors observe a clear increase in the number of deaths in both regions (Table 2). In Małopolska, the highest increase in the number of deaths occurred in the summer of 2010 in towns with a population below 10 thousand and in villages. In both cases, the number of deaths was $20 \%$ higher than expected. In the largest city of the region, the highest increase in the number of deaths, by $18.5 \%$, occurred in 2015. In Wielkopolska, the greatest increase in the number of deaths for all town sizes occurred during the summer of 1994. In towns with 25 to 50 thousand inhabitants, the number of deaths reached $146 \%$ of the expected number. In the largest city of the region, the increase in the number of deaths exceeded $30 \%$, and in the countryside, it was almost $24 \%$. The $25 \%$ increase in the number of deaths also occurred during the summer of 2010 in towns with a population of between 25 and 50 thousand.

Table 2. Heat-related mortality during the studied five summer periods calculated as percentage of the expected number of deaths during the time heatwave occurred. All natural causes and age groups are included. The $90 \%$ confidence intervals are in brackets. Statistically insignificant results are marked with *.

\begin{tabular}{|c|c|c|c|c|c|}
\hline Małopolska & & & Years & & \\
\hline Population & 1992 & 1994 & 2006 & 2010 & 2015 \\
\hline$>500 \mathrm{k}$ & $109.7(\mathrm{CI} \pm 3.3)$ & $113.4(\mathrm{CI} \pm 4.7)$ & $104.8(\mathrm{CI} \pm 2.6)$ & $116.3(\mathrm{CI} \pm 3.3)$ & $118.5(\mathrm{CI} \pm 1.3)$ \\
\hline $50 \mathrm{k}-150 \mathrm{k}$ & $109.5(\mathrm{CI} \pm 5.3)$ & *97.8 (CI \pm 2.3$)$ & $118.2(\mathrm{CI} \pm 3.5)$ & $114.1(\mathrm{CI} \pm 6.2)$ & $117.0(\mathrm{CI} \pm 5.8)$ \\
\hline $25 \mathrm{k}-50 \mathrm{k}$ & $111.3(\mathrm{CI} \pm 10.4)$ & $114.0(\mathrm{CI} \pm 7.7)$ & $108.4(\mathrm{CI} \pm 5.4)$ & * $95.0(\mathrm{CI} \pm 6.8)$ & $* 101.2(\mathrm{CI} \pm 4.5)$ \\
\hline $10 \mathrm{k}-25 \mathrm{k}$ & $111.0(\mathrm{CI} \pm 4.2)$ & $109.1(\mathrm{CI} \pm 4.5)$ & $105.3(\mathrm{CI} \pm 4.2)$ & $114.4(\mathrm{CI} \pm 4.3)$ & $113.8(\mathrm{CI} \pm 3.1)$ \\
\hline$<10 \mathrm{k}$ & * $107.2(\mathrm{CI} \pm 7.3)$ & $111.3(\mathrm{CI} \pm 7.8)$ & $110.8(\mathrm{CI} \pm 4.9)$ & $121.8(\mathrm{CI} \pm 13.4)$ & * $98.9(\mathrm{CI} \pm 4.9)$ \\
\hline Villages & * $101.5(\mathrm{CI} \pm 2.5)$ & $107.7(\mathrm{CI} \pm 2.6)$ & $103.4(\mathrm{CI} \pm 0.8)$ & $120.0(\mathrm{CI} \pm 1.7)$ & $112.2(\mathrm{CI} \pm 1.1)$ \\
\hline Wielkopolska & & & Years & & \\
\hline Population & 1992 & 1994 & 2006 & 2010 & 2015 \\
\hline$>500 \mathrm{k}$ & $111.7(\mathrm{CI} \pm 6.3)$ & $130.7(\mathrm{CI} \pm 10.1)$ & $110.0(\mathrm{CI} \pm 1.1)$ & $116.6(\mathrm{CI} \pm 3.9)$ & $115.1(\mathrm{CI} \pm 2.7)$ \\
\hline $50 \mathrm{k}-150 \mathrm{k}$ & $110.3(\mathrm{CI} \pm 4.9)$ & $139.9(\mathrm{CI} \pm 9.5)$ & $116.0(\mathrm{CI} \pm 2.5)$ & $115.9(\mathrm{CI} \pm 5.0)$ & $115.7(\mathrm{CI} \pm 5.9)$ \\
\hline $25 \mathrm{k}-50 \mathrm{k}$ & $110.0(\mathrm{CI} \pm 7.6)$ & $146.0(\mathrm{CI} \pm 12.3)$ & * $98.5(\mathrm{CI} \pm 6.1)$ & $125.7(\mathrm{CI} \pm 5.5)$ & $111.4(\mathrm{CI} \pm 1.9)$ \\
\hline $10 \mathrm{k}-25 \mathrm{k}$ & $112.2(\mathrm{CI} \pm 1.9)$ & $112.9(\mathrm{CI} \pm 4.7)$ & $110.4(\mathrm{CI} \pm 3.5)$ & $103.6(\mathrm{CI} \pm 3.2)$ & $109.3(\mathrm{CI} \pm 4.0)$ \\
\hline$<10 \mathrm{k}$ & $121.7(\mathrm{CI} \pm 7.7)$ & $127.9(\mathrm{CI} \pm 10.0)$ & $117.2(\mathrm{CI} \pm 4.2)$ & $117.2(\mathrm{CI} \pm 6.0)$ & $108.9(\mathrm{CI} \pm 5.0)$ \\
\hline Villages & $108.7(\mathrm{CI} \pm 5.3)$ & $123.8(\mathrm{CI} \pm 7.5)$ & $110.9(\mathrm{CI} \pm 2.1)$ & $114.6(\mathrm{CI} \pm 3.0)$ & $108.4(\mathrm{CI} \pm 2.0)$ \\
\hline
\end{tabular}

A smaller increase in the number of deaths became evident when a longer period was analyzed, including also 30 days after the heat wave finished (Table 3). In Małopolska, the number of deaths was higher than expected by over $15 \%$ only for locations with a population of less than 10 thousand in 1994 and 2006. In the largest city of the region (Kraków), 
the highest increase in the number of deaths (8.4\%) occurred in 2015. In Wielkopolska, as in the case of days during heat waves, the greatest increase in the number of deaths occurred in 1994. Regardless of the size of the town, the calculated increase in the number of deaths during this summer was statistically significant, and in towns with a population of 25-50 thousand, it even exceeded 20\%. In 2015, the increase in the number of deaths in the largest city of the region (Poznań) was lower than in other towns and villages.

Table 3. Heat-related mortality during the five summer periods calculated as percentage of the expected number of deaths. The period between the first sub-wave and the thirtieth day after the end of the last sub-wave. All causes of death and age groups are included. The $90 \%$ confidence intervals are in brackets. Statistically insignificant results are marked with *.

\begin{tabular}{|c|c|c|c|c|c|}
\hline Małopolska & & & Years & & \\
\hline Population & 1992 & 1994 & 2006 & 2010 & 2015 \\
\hline$>500 \mathrm{k}$ & $105.1(\mathrm{CI} \pm 2.3)$ & $107.8(\mathrm{CI} \pm 3.1)$ & $103.9(\mathrm{CI} \pm 1.8)$ & $105.6(\mathrm{CI} \pm 1.9)$ & $108.4(\mathrm{CI} \pm 2.2)$ \\
\hline $50 \mathrm{k}-150 \mathrm{k}$ & $* 103.0(\mathrm{CI} \pm 3.4)$ & * $100.5(\mathrm{CI} \pm 2.8)$ & $107.6(\mathrm{CI} \pm 2.9)$ & * $95.0(\mathrm{CI} \pm 3.9)$ & $106.2(\mathrm{CI} \pm 3.0)$ \\
\hline $25 \mathrm{k}-50 \mathrm{k}$ & $108.1(\mathrm{CI} \pm 7.5)$ & * $105.8(\mathrm{CI} \pm 6.2)$ & $104.6(\mathrm{CI} \pm 4.5)$ & $* 98.4(\mathrm{CI} \pm 3.5)$ & $106.3(\mathrm{CI} \pm 2.3)$ \\
\hline $10 \mathrm{k}-25 \mathrm{k}$ & $106.1(\mathrm{CI} \pm 3.6)$ & $107.2(\mathrm{CI} \pm 4.5)$ & $106.7(\mathrm{CI} \pm 2.3)$ & * $100.3(\mathrm{CI} \pm 3.9)$ & $* 100.1(\mathrm{CI} \pm 2.1)$ \\
\hline$<10 \mathrm{k}$ & $* 102.2(\mathrm{CI} \pm 4.0)$ & $115.1(\mathrm{CI} \pm 6.9)$ & $118.7(\mathrm{CI} \pm 4.3)$ & $* 98.9(\mathrm{CI} \pm 6.3)$ & $* 98.7(\mathrm{CI} \pm 3.6)$ \\
\hline Villages & * 101.2 (CI \pm 1.5$)$ & $104.3(\mathrm{CI} \pm 1.6)$ & $102.7(\mathrm{CI} \pm 1.0)$ & $102.1(\mathrm{CI} \pm 1.6)$ & $103.7(\mathrm{CI} \pm 1.2)$ \\
\hline Wielkopolska & & & Years & & \\
\hline Population & 1992 & 1994 & 2006 & 2010 & 2015 \\
\hline$>500 \mathrm{k}$ & $* 104.0(\mathrm{CI} \pm 5.0)$ & $117.4(\mathrm{CI} \pm 6.4)$ & $105.6(\mathrm{CI} \pm 1.7)$ & $105.8(\mathrm{CI} \pm 2.2)$ & $103.0(\mathrm{CI} \pm 2.2)$ \\
\hline $50 \mathrm{k}-150 \mathrm{k}$ & $104.6(\mathrm{CI} \pm 3.5)$ & $119.8(\mathrm{CI} \pm 6.0)$ & $111.5(\mathrm{CI} \pm 3.1)$ & * $99.7(\mathrm{CI} \pm 3.2)$ & $110.5(\mathrm{CI} \pm 3.8)$ \\
\hline $25 \mathrm{k}-50 \mathrm{k}$ & *99.6(CI \pm 3.2$)$ & $120.4(\mathrm{CI} \pm 6.8)$ & $* 100.2(\mathrm{CI} \pm 4.7)$ & $101.9(\mathrm{CI} \pm 3.2)$ & $108.0(\mathrm{CI} \pm 3.0)$ \\
\hline $10 \mathrm{k}-25 \mathrm{k}$ & $106.3(\mathrm{CI} \pm 2.3)$ & $109.1(\mathrm{CI} \pm 2.9)$ & $104.9(\mathrm{CI} \pm 2.7)$ & * $97.5(\mathrm{CI} \pm 3.4)$ & $108.1(\mathrm{CI} \pm 4.1)$ \\
\hline$<10 \mathrm{k}$ & $109.5(\mathrm{CI} \pm 3.5)$ & $114.6(\mathrm{CI} \pm 5.7)$ & $107.4(\mathrm{CI} \pm 4.0)$ & $103.5(\mathrm{CI} \pm 2.5)$ & $108.2(\mathrm{CI} \pm 2.8)$ \\
\hline Villages & $103.8(\mathrm{CI} \pm 3.3)$ & $114.1(\mathrm{CI} \pm 4.6)$ & $104.5(\mathrm{CI} \pm 1.2)$ & $* 101.5(\mathrm{CI} \pm 2.1)$ & $106.0(\mathrm{CI} \pm 1.0)$ \\
\hline
\end{tabular}

3.3.2. Deaths Caused by Cardiovascular Diseases, Increased Number of Deaths in Analyzed Regions

The increase in the number of deaths caused by cardiovascular diseases (Table 4) was lower in Małopolska than in the case of all natural causes. Still, most of the recorded increases in mortality were statistically significant. In the largest city of the region, Kraków, it increased by $22.5 \%$ in 2015 and a high value (17.5\%) was also recorded in 1994. Except for 2010 and 2015 , statistically significant increases from $12 \%$ to $22.5 \%$ were recorded in towns with a population of 25-50 thousand. For villages, a relatively large increase, exceeding $12 \%$, was recorded in 2010 and 2015. The increase in mortality in the Wielkopolska region was clearly greater. In 1994, in towns with a population of 25-50 thousand, the number of deaths was $66.3 \%$ higher than expected. A large increase in the number of deaths (38.3\%) in towns of this size was also calculated for the heat wave of 2010. A statistically significant increase, except for 2015, was also observed for towns with a population of less than 10 thousand. For rural areas, a statistically significant increase in the number of deaths from $6.3 \%$ to $15 \%$ was recorded for all analyzed summer periods.

The analysis of the longer period, including the days between heat sub-waves and the period of 30 days after the end of the last sub-wave (Table 5), showed that, in Małopolska, a significant increase in the number of deaths during heat waves may have been partially related to the so-called harvesting effect. This means that during the heatwaves, people were dying who were in poor health, and would most likely have died in the coming weeks even if the heatwave had not occurred. Only in the case of Kraków (Małopolska), the increase in the number of deaths was most often clear and statistically significant. A statistically significant increase in the number of deaths exceeding $20 \%$ occurred during the heat wave of 1992 for towns with a population of 25-50 thousand and in 2006 for towns with a population below 10 thousand residents. In the Wielkopolska region, only in 1994 was an increase in the number of deaths exceeding $20 \%$ recorded for towns with a population of 25-50 thousand. This year, apart from municipalities with a population of 10-25 thousand, there were statistically significant increases in the number of deaths. The 
largest increase $(17 \%)$ in mortality caused by cardiovascular diseases during heatwaves for villages in Wielkopolska occurred in 2006.

Table 4. Mortality from cardiovascular diseases during heatwaves calculated as percentage of the expected number of deaths during the time heatwave occurred. The $90 \%$ confidence intervals are in brackets. Statistically insignificant results are marked with *.

\begin{tabular}{|c|c|c|c|c|c|}
\hline Małopolska & & & Years & & \\
\hline Population & 1992 & 1994 & 2006 & 2010 & 2015 \\
\hline$>500 \mathrm{k}$ & $109.6(\mathrm{CI} \pm 6.5)$ & $117.5(\mathrm{CI} \pm 6.6)$ & $107.7(\mathrm{CI} \pm 3.8)$ & * $102.7(\mathrm{CI} \pm 5.6)$ & $122.5(\mathrm{CI} \pm 3.5)$ \\
\hline $50 \mathrm{k}-150 \mathrm{k}$ & * $113.1(\mathrm{CI} \pm 16.4)$ & * $97.7(\mathrm{CI} \pm 7.3)$ & * $98.7(\mathrm{CI} \pm 3.9)$ & $107.1(\mathrm{CI} \pm 6.2)$ & $105.4(\mathrm{CI} \pm 5.3)$ \\
\hline $25 \mathrm{k}-50 \mathrm{k}$ & $122.5(\mathrm{CI} \pm 16.8)$ & $118.6(\mathrm{CI} \pm 11.9)$ & $112.1(\mathrm{CI} \pm 5.3)$ & * $93.5(\mathrm{CI} \pm 11.0)$ & $102.4(\mathrm{CI} \pm 7.2)$ \\
\hline $10 \mathrm{k}-25 \mathrm{k}$ & $* 96.8(\mathrm{CI} \pm 8.8)$ & $109.1(\mathrm{CI} \pm 7.3)$ & $101.0(\mathrm{CI} \pm 6.4)$ & $116.6(\mathrm{CI} \pm 8.3)$ & $106.8(\mathrm{CI} \pm 5.2)$ \\
\hline$<10 \mathrm{k}$ & * $99.5(\mathrm{CI} \pm 8.3)$ & $* 103.5(\mathrm{CI} \pm 5.5)$ & $119.6(\mathrm{CI} \pm 3.9)$ & $104.5(\mathrm{CI} \pm 7.3)$ & $* 96.7(\mathrm{CI} \pm 7.1)$ \\
\hline Villages & * $102.3(\mathrm{CI} \pm 4.0)$ & $107.5(\mathrm{CI} \pm 3.2)$ & $105.0(\mathrm{CI} \pm 3.4)$ & $117.9(\mathrm{CI} \pm 2.7)$ & $112.9(\mathrm{CI} \pm 2.4)$ \\
\hline Wielkopolska & & & Years & & \\
\hline Population & 1992 & 1994 & 2006 & 2010 & 2015 \\
\hline$>500 \mathrm{k}$ & $111.2(\mathrm{CI} \pm 10.9)$ & $123.1(\mathrm{CI} \pm 12.0)$ & $104.1(\mathrm{CI} \pm 3.1)$ & $113.5(\mathrm{CI} \pm 4.3)$ & $117.4(\mathrm{CI} \pm 10.1)$ \\
\hline $50 \mathrm{k}-150 \mathrm{k}$ & * $107.6(\mathrm{CI} \pm 9.8)$ & $132.0(\mathrm{CI} \pm 10.3)$ & $124.6(\mathrm{CI} \pm 2.1)$ & $132.4(\mathrm{CI} \pm 9.9)$ & $105.5(\mathrm{CI} \pm 4.5)$ \\
\hline $25 \mathrm{k}-50 \mathrm{k}$ & * $111.7(\mathrm{CI} \pm 13.8)$ & $166.3(\mathrm{CI} \pm 18.8)$ & $* 97.9(\mathrm{CI} \pm 9.6)$ & $138.3(\mathrm{CI} \pm 7.8)$ & $* 100.8(\mathrm{CI} \pm 7.6)$ \\
\hline $10 \mathrm{k}-25 \mathrm{k}$ & $119.8(\mathrm{CI} \pm 4.2)$ & $111.5(\mathrm{CI} \pm 7.5)$ & * $102.3(\mathrm{CI} \pm 4.3)$ & $104.6(\mathrm{CI} \pm 4.2)$ & $107.4(\mathrm{CI} \pm 3.2)$ \\
\hline$<10 \mathrm{k}$ & $134.3(\mathrm{CI} \pm 18.0)$ & $115.4(\mathrm{CI} \pm 10.7)$ & $115.7(\mathrm{CI} \pm 6.1)$ & $122.8(\mathrm{CI} \pm 7.0)$ & ${ }^{*} 104.1(\mathrm{CI} \pm 8.1)$ \\
\hline Villages & $* 107.6(\mathrm{CI} \pm 10.1)$ & $115.8(\mathrm{CI} \pm 8.5)$ & $117.6(\mathrm{CI} \pm 2.1)$ & $115.8(\mathrm{CI} \pm 4.9)$ & $106.3(\mathrm{CI} \pm 4.1)$ \\
\hline
\end{tabular}

Table 5. Mortality from cardiovascular diseases during heatwaves calculated as percentage of the expected number of deaths. The period between the first sub-wave and the thirtieth day after the end of the last sub-wave. The $90 \%$ confidence intervals are in brackets. Statistically insignificant results are marked with *.

\begin{tabular}{|c|c|c|c|c|c|}
\hline Małopolska & & & Years & & \\
\hline Population & 1992 & 1994 & 2006 & 2010 & 2015 \\
\hline$>500 \mathrm{k}$ & $109.7(\mathrm{CI} \pm 4.6)$ & $108.8(\mathrm{CI} \pm 4.1)$ & $104.5(\mathrm{CI} \pm 3.3)$ & * $102.2(\mathrm{CI} \pm 3.5)$ & $114.3(\mathrm{CI} \pm 1.7)$ \\
\hline $50 \mathrm{k}-150 \mathrm{k}$ & * $107.2(\mathrm{CI} \pm 9.0)$ & $* 103.7(\mathrm{CI} \pm 4.8)$ & * $97.0(\mathrm{CI} \pm 9.3)$ & $* 91.5(\mathrm{CI} \pm 5.5)$ & * $99.8(\mathrm{CI} \pm 6.6)$ \\
\hline $25 \mathrm{k}-50 \mathrm{k}$ & $122.2(\mathrm{CI} \pm 11.8)$ & * $107.9(\mathrm{CI} \pm 9.6)$ & $112.3(\mathrm{CI} \pm 5.4)$ & * $99.4(\mathrm{CI} \pm 3.9)$ & $106.6(\mathrm{CI} \pm 4.4)$ \\
\hline $10 \mathrm{k}-25 \mathrm{k}$ & * $98.7(\mathrm{CI} \pm 6.3)$ & * $101.1(\mathrm{CI} \pm 6.0)$ & $104.0(\mathrm{CI} \pm 2.7)$ & $* 96.8(\mathrm{CI} \pm 5.2)$ & * $94.5(\mathrm{CI} \pm 3.5)$ \\
\hline$<10 \mathrm{k}$ & $* 94.0(\mathrm{CI} \pm 4.7)$ & $109.8(\mathrm{CI} \pm 4.3)$ & $123.4(\mathrm{CI} \pm 3.5)$ & $* 97.4(\mathrm{CI} \pm 7.0)$ & * $99.0(\mathrm{CI} \pm 7.2)$ \\
\hline Villages & ${ }^{*} 101.4(\mathrm{CI} \pm 2.0)$ & * $103.3(\mathrm{CI} \pm 2.0)$ & $* 101.2(\mathrm{CI} \pm 3.7)$ & * $101.2(\mathrm{CI} \pm 2.5)$ & $105.0(\mathrm{CI} \pm 2.1)$ \\
\hline Wielkopolska & & & Years & & \\
\hline Population & 1992 & 1994 & 2006 & 2010 & 2015 \\
\hline$>500 \mathrm{k}$ & * $102.1(\mathrm{CI} \pm 8.5)$ & $112.4(\mathrm{CI} \pm 7.7)$ & * $100.4(\mathrm{CI} \pm 3.0)$ & * $104.8(\mathrm{CI} \pm 5.8)$ & $* 102.1(\mathrm{CI} \pm 8.5)$ \\
\hline $50 \mathrm{k}-150 \mathrm{k}$ & $107.8(\mathrm{CI} \pm 7.2)$ & $119.1(\mathrm{CI} \pm 8.5)$ & $112.0(\mathrm{CI} \pm 2.1)$ & $107.2(\mathrm{CI} \pm 2.5)$ & $107.8(\mathrm{CI} \pm 7.2)$ \\
\hline $25 \mathrm{k}-50 \mathrm{k}$ & *97.4 (CI \pm 7.7$)$ & $126.5(\mathrm{CI} \pm 10.6)$ & * $99.8(\mathrm{CI} \pm 6.5)$ & $* 95.8(\mathrm{CI} \pm 5.8)$ & * $97.4(\mathrm{CI} \pm 7.7)$ \\
\hline $10 \mathrm{k}-25 \mathrm{k}$ & $110.4(\mathrm{CI} \pm 3.9)$ & $* 102.1(\mathrm{CI} \pm 3.1)$ & $104.4(\mathrm{CI} \pm 3.5)$ & * $103.1(\mathrm{CI} \pm 4.2)$ & $110.4(\mathrm{CI} \pm 3.9)$ \\
\hline$<10 \mathrm{k}$ & $115.2(\mathrm{CI} \pm 9.9)$ & $108.5(\mathrm{CI} \pm 8.9)^{\prime}$ & * $103.4(\mathrm{CI} \pm 5.4)$ & $* 104.5(\mathrm{CI} \pm 4.7)$ & $115.2(\mathrm{CI} \pm 9.9)$ \\
\hline Villages & $107.4(\mathrm{CI} \pm 6.1)$ & $105.9(\mathrm{CI} \pm 5.5)$ & $110.0(\mathrm{CI} \pm 2.0)$ & $* 100.5(\mathrm{CI} \pm 3.7)$ & $107.4(\mathrm{CI} \pm 6.1)$ \\
\hline
\end{tabular}

\subsubsection{Deaths in the Age Group 65 and Older}

Age has proved to be a significant risk factor in both regions and during certain heat waves (Table 6). In the Małopolska region in 2010, apart from towns with a population of 25 to 50 thousand and in 2015, except for cities with 50-150 thousand inhabitants, the increases in the number of deaths were statistically significant and exceeded $10 \%$. In 2015, in towns with a population of 10-25 thousand, the number of deaths was over $24 \%$ higher than in the reference period. In the villages of Małopolska, apart from the heat wave of 1992, there was also a clear and statistically significant increase in the number of deaths in 2010; it exceeded 17\%. A much higher increase in the number of deaths occurred in the Wielkopolska region in 1994. In municipalities with a population of 25-50 thousand, the number of deaths was higher than expected by $87 \%$, and the smallest, but still very visible, increase in the number of deaths was observed in towns with the number of inhabitants ranging from 10-25 thousand. In the smallest towns, the increase in the number of deaths 
was clear and statistically significant during all analyzed summer periods: from $18.2 \%$ in 2010 to almost $40 \%$ in 1994. Statistically significant, although slightly lower increases in mortality (from $6.8 \%$ to $27 \%$ ) were recorded in rural areas.

Table 6. Heat-related mortality during the studied five summer periods calculated as percentage of the expected number of deaths during the time heatwave occurred. Subpopulation age 65 and older is analyzed. The $90 \%$ confidence intervals are in brackets. Statistically insignificant results are marked with *

\begin{tabular}{|c|c|c|c|c|c|}
\hline Małopolska & & & Years & & \\
\hline Population & 1992 & 1994 & 2006 & 2010 & 2015 \\
\hline$>500 \mathrm{k}$ & $108.5(\mathrm{CI} \pm 2.5)$ & $113.2(\mathrm{CI} \pm 4.4)$ & $104.4(\mathrm{CI} \pm 3.2)$ & $113.0(\mathrm{CI} \pm 4.1)$ & $119.0(\mathrm{CI} \pm 2.4)$ \\
\hline $50 \mathrm{k}-150 \mathrm{k}$ & $109.7(\mathrm{CI} \pm 7.3)$ & * $98.9(\mathrm{CI} \pm 4.3)$ & $114.8(\mathrm{CI} \pm 9.3)$ & $110.1(\mathrm{CI} \pm 6.3)$ & $* 104.9(\mathrm{CI} \pm 6.1)$ \\
\hline $25 \mathrm{k}-50 \mathrm{k}$ & $117.8(\mathrm{CI} \pm 6.4)$ & $120.3(\mathrm{CI} \pm 7.8)$ & $107.1(\mathrm{CI} \pm 6.2)$ & $* 94.9(\mathrm{CI} \pm 7.5)$ & $119.2(\mathrm{CI} \pm 6.6)$ \\
\hline $10 \mathrm{k}-25 \mathrm{k}$ & * $102.7(\mathrm{CI} \pm 4.0)$ & $118.7(\mathrm{CI} \pm 5.5)$ & * $104.6(\mathrm{CI} \pm 4.8)$ & $112.6(\mathrm{CI} \pm 6.3)$ & $124.3(\mathrm{CI} \pm 4.3)$ \\
\hline$<10 \mathrm{k}$ & $* 101.3(\mathrm{CI} \pm 5.3)$ & * $105.3(\mathrm{CI} \pm 6.3)$ & $108.8(\mathrm{CI} \pm 4.9)$ & $127.1(\mathrm{CI} \pm 15.2)$ & $118.0(\mathrm{CI} \pm 8.9)$ \\
\hline Villages & * $102.4(\mathrm{CI} \pm 2.3)$ & $109.1(\mathrm{CI} \pm 2.6)$ & $106.5(\mathrm{CI} \pm 1.7)$ & $117.2(\mathrm{CI} \pm 1.7)$ & $112.1(\mathrm{CI} \pm 1.5)$ \\
\hline Wielkopolska & & & Years & & \\
\hline Population & 1992 & 1994 & 2006 & 2010 & 2015 \\
\hline$>500 \mathrm{k}$ & $115.1(\mathrm{CI} \pm 3.9)$ & $139.0(\mathrm{CI} \pm 12.5)$ & $114.5(\mathrm{CI} \pm 2.2)$ & $115.8(\mathrm{CI} \pm 4.1)$ & $120.8(\mathrm{CI} \pm 3.5)$ \\
\hline $50 \mathrm{k}-150 \mathrm{k}$ & $108.2(\mathrm{CI} \pm 3.8)$ & $151.7(\mathrm{CI} \pm 13.0)$ & $115.1(\mathrm{CI} \pm 3.6)$ & $107.6(\mathrm{CI} \pm 6.2)$ & $120.6(\mathrm{CI} \pm 6.9)$ \\
\hline $25 \mathrm{k}-50 \mathrm{k}$ & $110.2(\mathrm{CI} \pm 8.1)$ & $187.1(\mathrm{CI} \pm 22.2)$ & * $99.1(\mathrm{CI} \pm 9.9)$ & $121.5(\mathrm{CI} \pm 8.4)$ & $116.9(\mathrm{CI} \pm 3.0)$ \\
\hline $10 \mathrm{k}-25 \mathrm{k}$ & $* 101.9(\mathrm{CI} \pm 4.1)$ & $124.1(\mathrm{CI} \pm 8.1)$ & $117.5(\mathrm{CI} \pm 4.0)$ & * $98.7(\mathrm{CI} \pm 3.9)$ & $114.3(\mathrm{CI} \pm 4.7)$ \\
\hline$<10 \mathrm{k}$ & $121.3(\mathrm{CI} \pm 9.1)$ & $139.9(\mathrm{CI} \pm 13.4)$ & $125.3(\mathrm{CI} \pm 3.9)$ & $118.2(\mathrm{CI} \pm 8.3)$ & $124.2(\mathrm{CI} \pm 6.7)$ \\
\hline Villages & $106.8(\mathrm{CI} \pm 5.2)$ & $127.5(\mathrm{CI} \pm 8.4)$ & $116.0(\mathrm{CI} \pm 2.6)$ & $113.5(\mathrm{CI} \pm 5.1)$ & $109.3(\mathrm{CI} \pm 2.8)$ \\
\hline
\end{tabular}

The increase in the number of deaths in both regions turned out to be only partially characterized with a shift in the time of deaths of people aged 65 and older. For a longer period, also including 30 days after the end of heat waves (Table 7), in the largest city of Małopolska, the increase in the number of deaths in 2010 was higher by $10.1 \%$ and in 1994 by $7.5 \%$. For municipalities from 25 to 50 thousand inhabitants, a large and statistically significant increase occurred in 1992, 1994 and 2015. It was $16.0 \%, 9.2 \%$ and $15.2 \%$, respectively. Even more unambiguous results were obtained for the area of Wielkopolska. Similar results were obtained as in the previously discussed subpopulations (Tables 3 and 5).

Table 7. Heat-related mortality during the five summer periods calculated as percentage of the expected number of deaths. The period between the first sub-wave and the thirtieth day after the end of the last sub-wave. Subpopulation age 65 and older is analyzed. The $90 \%$ confidence intervals are in brackets. Statistically insignificant results are marked with *.

\begin{tabular}{|c|c|c|c|c|c|}
\hline Małopolska & & & Years & & \\
\hline Population & 1992 & 1994 & 2006 & 2010 & 2015 \\
\hline$>500 \mathrm{k}$ & $104.3(\mathrm{CI} \pm 1.3)$ & $107.5(\mathrm{CI} \pm 2.8)$ & $103.6(\mathrm{CI} \pm 1.8)$ & $104.1(\mathrm{CI} \pm 2.3)$ & $110.3(\mathrm{CI} \pm 2.5)$ \\
\hline $50 \mathrm{k}-150 \mathrm{k}$ & $109.4(\mathrm{CI} \pm 2.5)$ & $106.8(\mathrm{CI} \pm 2.9)$ & * $101.7(\mathrm{CI} \pm 3.3)$ & $* 96.2(\mathrm{CI} \pm 5.7)$ & $106.4(\mathrm{CI} \pm 2.5)$ \\
\hline $25 \mathrm{k}-50 \mathrm{k}$ & $116.0(\mathrm{CI} \pm 4.2)$ & $109.2(\mathrm{CI} \pm 4.4)$ & $106.6(\mathrm{CI} \pm 5.9)$ & $100.1(\mathrm{CI} \pm 6.0)$ & $115.2(\mathrm{CI} \pm 4.6)$ \\
\hline $10 \mathrm{k}-25 \mathrm{k}$ & * $97.5(\mathrm{CI} \pm 4.0)$ & $110.5(\mathrm{CI} \pm 6.3)$ & $110.8(\mathrm{CI} \pm 3.1)$ & $* 98.4(\mathrm{CI} \pm 6.1)$ & $105.4(\mathrm{CI} \pm 4.5)$ \\
\hline$<10 \mathrm{k}$ & $* 94.6(\mathrm{CI} \pm 4.3)$ & $110.8(\mathrm{CI} \pm 4.8)$ & $121.6(\mathrm{CI} \pm 3.9)$ & * $95.5(\mathrm{CI} \pm 9.0)$ & $108.7(\mathrm{CI} \pm 5.0)$ \\
\hline Villages & * $100.3(\mathrm{CI} \pm 2.0)$ & $104.2(\mathrm{CI} \pm 2.0)$ & $103.7(\mathrm{CI} \pm 1.5)$ & $101.7(\mathrm{CI} \pm 1.7)$ & $104.8(\mathrm{CI} \pm 2.1)$ \\
\hline Wielkopolska & & & Years & & \\
\hline Population & 1992 & 1994 & 2006 & 2010 & 2015 \\
\hline$>500 \mathrm{k}$ & $105.6(\mathrm{CI} \pm 3.2)$ & $123.3(\mathrm{CI} \pm 7.2)$ & $111.0(\mathrm{CI} \pm 2.4)$ & $105.4(\mathrm{CI} \pm 3.2)$ & $106.2(\mathrm{CI} \pm 2.8)$ \\
\hline $50 \mathrm{k}-150 \mathrm{k}$ & $103.8(\mathrm{CI} \pm 3.2)$ & $126.8(\mathrm{CI} \pm 7.6)$ & $108.1(\mathrm{CI} \pm 3.5)$ & * $95.0(\mathrm{CI} \pm 4.1)$ & $116.4(\mathrm{CI} \pm 5.7)$ \\
\hline $25 \mathrm{k}-50 \mathrm{k}$ & * $96.1(\mathrm{CI} \pm 2.9)$ & $141.0(\mathrm{CI} \pm 11.5)$ & * $98.4(\mathrm{CI} \pm 6.4)$ & * $97.6(\mathrm{CI} \pm 4.1)$ & $114.0(\mathrm{CI} \pm 5.2)$ \\
\hline $10 \mathrm{k}-25 \mathrm{k}$ & $104.2(\mathrm{CI} \pm 2.8)$ & $112.7(\mathrm{CI} \pm 4.9)$ & $108.9(\mathrm{CI} \pm 3.3)$ & * $96.5(\mathrm{CI} \pm 3.3)$ & $112.6(\mathrm{CI} \pm 5.7)$ \\
\hline$<10 \mathrm{k}$ & $107.7(\mathrm{CI} \pm 4.6)$ & $118.1(\mathrm{CI} \pm 7.3)$ & $111.1(\mathrm{CI} \pm 4.4)$ & $105.1(\mathrm{CI} \pm 2.5)$ & $116.7(\mathrm{CI} \pm 4.1)$ \\
\hline Villages & $* 102.6(\mathrm{CI} \pm 3.0)$ & $115.7(\mathrm{CI} \pm 4.8)$ & $108.9(\mathrm{CI} \pm 1.9)$ & * $99.9(\mathrm{CI} \pm 2.7)$ & $107.8(\mathrm{CI} \pm 2.1)$ \\
\hline
\end{tabular}




\section{Summary and Discussion}

The analysis of the relation between the maximum daily air temperature and the risk of death showed that for the largest cities, the risk of death is clear and statistically significant for all analyzed risk groups. In smaller towns, the relationship is also visible, but especially in Małopolska for the risk group associated with heart disease and age, it is often statistically insignificant. The lack of statistical significance may be due to the fact that smaller populations were studied where there are days without any deaths, even during heat waves. The increase in the risk of death for these risk groups was also observed and statistically significant for villages in both regions, although the value of the relative risk of death was generally lower than for large towns. The risk of death related to high temperature values was different in both analyzed periods. In Wielkopolska, for all risk groups and town size ranges, the increase in the risk of death was higher in the period 1989-1998. In Małopolska, the opposite was most often the case, i.e., in the later of analyzed periods, the risk of death was higher with increasing temperature.

The heat waves analyzed in this study were unique in terms of prevailing weather conditions. They were also the subject of other studies also in neighbouring countries. The heat waves of 1992, 1994, 2006, 2010 and 2015 were also analyzed in [33] and the most persistent heat waves were recognised as those of 1994 and 2015. Additionally, in [34], based on the human-biometeorological index Physiologically Equivalent Temperature (PET), these two summer periods were distinguished as particularly unfavorable, considering that the most strenuous conditions occurred in 1994. This is largely due to the obtained results of increased mortality directly during the heat wave. In both analyzed regions, in those years, the greatest increase in mortality was observed, almost always statistically significant, regardless of the size of the town. In 1994, statistically insignificant results were obtained only for towns with 50 to 150 thousand inhabitants in the Małopolska region. In 2015 , no statistically significant increase in the number of deaths occurred in municipalities with a population of less than 10 thousand and of 10-25 thousand people. Taking into account the longer period, also including 30 days after the end of the last heat wave, the results were similar, which proves that most of the so-called additional deaths did not only result from the time shifted mortality.

Heart and cardiovascular system diseases are a serious factor that increases the risk of mortality from heat waves. This is confirmed by previous studies and analyses [13,35-37]. In the literature, one can find both studies in which the problem of increased mortality during heat waves concerns mainly large towns [38] and those that state that populations living in agricultural areas may be more vulnerable to heat [39]. In the regions analyzed in the present study, in the largest cities, during almost every heat wave, we note a clear and statistically significant increase in the number of deaths related to cardiovascular diseases. The situation is similar in the case of rural areas, except for 1994, when the increase in the number of deaths in both regions is not statistically significant. In small and medium-sized towns, the results are less clear-cut, especially in Małopolska, where in many cases there is no increase in the number of deaths, or this increase is not statistically significant. In the Wielkopolska region, there is a higher number of statistically significant increases in the number of deaths in smaller towns, e.g., a 66\% increase in cities with 25-50 thousand inhabitants. In both regions, however, a large part of the recorded increases in heart diseaserelated mortality is due to the so-called harvesting effect. Within 30 days after the end of the last sub-wave, days with the number of deaths below the expected rate are dominating. This leads to the conclusion that in some years, e.g., 2010, in both regions, except for large towns, we do not record a statistically significant increase in the number of deaths. During the hottest summer of 1994 in the Wielkopolska region, apart from cities with a population of 10-25 thousand, there was a very clear increase in the number of deaths $(26.5 \%)$ in cities with a population of 25-50 thousand.

In several studies, e.g., [40-42], advanced age is also considered an important risk factor. The common finding is that the risk of dying from heat waves rises as age increases or is higher beyond a certain age. Additionally, the results of analyses carried out in the 
studied regions lead to the conclusion that mortality during heat waves is increasing. In the case of the largest cities in both regions, for each of the summer periods, the increase in the number of deaths is clear and statistically significant. In the case of smaller towns and villages, especially in Małopolska, there are also increases that are not statistically significant, but they constitute a definite minority. In 1994, in Wielkopolska, the number of deaths in towns of 25-50 thousand inhabitants was $87 \%$ higher than expected. The vast majority of mortality rates did not fall below the expected value in the next 30 days, which allows us to state that they do not result from the time-shifted mortality.

There were significant differences in mortality during the analyzed heatwaves between the studied regions. The increase in the number of deaths was usually greater in Wielkopolska and it applied not only to the largest cities in both regions, but also to smaller towns and villages. In a greater number of cases, the observed increase in mortality was statistically significant. This was especially true in the case of deaths related to cardiovascular diseases. Regional differences in that matter have also been identified in earlier studies. For example, it has been observed that in coastal towns it is smaller than in the hinterland [43]. In this case, however, we are dealing with regions located far from the sea. Lower mortality rates in Małopolska may be resulting from the location of some towns higher above sea level, where lower temperatures during the hottest days should appear. This is not obvious, however, because some studies show that populations in cooler regions are more sensitive to heat waves than those in warmer regions [44,45].

Because of the fact that the problem of increased mortality during heat waves is already present and concerns large cities and villages, it is necessary to create appropriate regional strategies to reduce the risk of death in the most vulnerable groups. Moreover, in the future, due to the further warming of the climate and the aging of the population in Poland, more people will be at risk. Various strategies for reducing the risk of additional deaths during heat waves, methods for reducing the nuisance of heat waves, and the possible applications of the results obtained in creating local plans are presented in $[23,46,47]$.

\section{Limitations of the Study}

There are few issues that need to be mentioned that are behind some limitations of the research. In the years 1997-1998, protest action by physicians took place in Poland. One of the few forms of protest was the refusal to specify the cause of death in official documents. The scale of the protest was not large, but is not fully known, and may have contributed to the calculated increase in deaths related to cardiovascular disease. In the last two decades, there have been significant demographic changes in Poland. Part of the population of large but also smaller towns and villages settled in satellite towns to the largest cities in the region. These were usually young families with children who, due to their age and health condition, are less susceptible to the harmful effects of heat waves. This may result in the calculated increase in the risk of deaths being lower than it actually is. During the analyzed period, the population increased in both regions: in Małopolska, by about 5\%, from 3190 million in 1995 to 3380 in 2016 and in Greater Poland, by over 4\%, from 3332 million in 1995 to 3482 in 2016. Obtaining more accurate results would require further analyses enriched with demographic and socio-economic factors.

\section{Conclusions}

1. We observed a clear and statistically significant relationship between the risk of death and temperature in the largest cities of both regions. It is most likely related to the urban heat island effect, the intensity of which is highest in the largest cities of both regions. In smaller towns and villages, the risk of death was generally lower, but still high enough to be considered as an important problem.

2. In the largest towns, the increase in the number of deaths during heat waves is clear and statistically significant during all summer periods with particularly unfavorable thermal conditions. 
3. The rise in heatwave mortality is not just a problem of large agglomerations. During the longest and most intense of heatwaves, a clear and statistically significant increase in mortality is also observed in smaller towns and in rural areas.

4. There are differences in the increase in mortality between regions, indicating greater vulnerability to heat-related mortality in the lowland and plains in the Wielkopolska region.

5. The increase in the number of deaths during heatwaves in some smaller towns, especially in the case of deaths related to cardiovascular diseases, is the result of time-shifted mortality (so-called harvesting effect).

6. The presented studies, supplemented with demographic analyses and models showing in more detail the climatic conditions, may in future be used to create local strategies to reduce health risks associated with heat waves and to identify the areas that are most at risk.

Supplementary Materials: The following supporting information can be downloaded at: https: / / www.mdpi.com/article/10.3390/atmos13030390/s1, Figure S1: Relation between daily maximum temperature and relative mortality risk (all non-accidental causes) in warm months (June-September) for: (a) Poznań 1989-1998; (b) Kraków 1989-1998; (c) Poznań 2001-2016; (d) Kraków 2001-2016; Figure S2: Relation between daily maximum temperature and relative mortality risk (cardiovascular diseases) in warm months (June-September) for: (a) Poznań 1989-1998; (b) Kraków 1989-1998; (c) Poznań 2001-2016; (d) Kraków 2001-2016; Figure S3: Relation between daily maximum temperature and relative mortality risk (age 65 and older) in warm months (June-September) for: (a) Poznań 1989-1998; (b) Kraków 1989-1998; (c) Poznań 2001-2016; (d) Kraków 2001-2016; Figure S4: Relation between daily maximum temperature and relative mortality risk (all non-accidental causes) in warm months (June-September) for towns with population of 50-150 thousand: (a) Wielkopolska 1989-1998; (b) Małopolska 1989-1998; (c) Wielkopolska 2001-2016; (d) Małopolska 2001-2016; Figure S5: Relation between daily maximum temperature and relative mortality risk (cardiovascular diseases) in warm months (June-September) for towns with population of 50-150 thousand: (a) Wielkopolska 1989-1998; (b) Małopolska 1989-1998; (c) Wielkopolska 2001-2016; (d) Małopolska 2001-2016; Figure S6: Relation between daily maximum temperature and relative mortality risk (age 65 and older) in warm months (June-September) for towns with population of 50-150 thousand: (a) Wielkopolska 1989-1998; (b) Małopolska 1989-1998; (c) Wielkopolska 2001-2016; (d) Małopolska 2001-2016; Figure S7: Relation between daily maximum temperature and relative mortality risk (all non-accidental causes) in warm months (June-September) for towns with population of 25-50 thousand: (a) Wielkopolska 1989-1998; (b) Małopolska 1989-1998; (c) Wielkopolska 2001-2016; (d) Małopolska 2001-2016; Figure S8: Relation between daily maximum temperature and relative mortality risk (cardiovascular diseases) in warm months (June-September) for towns with population of 25-50 thousand: (a) Wielkopolska 1989-1998; (b) Małopolska 1989-1998; (c) Wielkopolska 2001-2016; (d) Małopolska 2001-2016; Figure S9: Relation between daily maximum temperature and relative mortality risk (age 65 and older) in warm months (June-September) for towns with population of 25-50 thousand: (a) Wielkopolska 1989-1998; (b) Małopolska 1989-1998; (c) Wielkopolska 2001-2016; (d) Małopolska 2001-2016; Figure S10: Relation between daily maximum temperature and relative mortality risk (all non-accidental causes) in warm months (June-September) for towns with population of 10-25 thousand: (a) Wielkopolska 1989-1998; (b) Małopolska 1989-1998; (c) Wielkopolska 2001-2016; (d) Małopolska 2001-2016; Figure S11: Relation between daily maximum temperature and relative mortality risk (cardiovascular diseases) in warm months (June-September) for towns with population of 10-25 thousand: (a) Wielkopolska 1989-1998; (b) Małopolska 1989-1998; (c) Wielkopolska 2001-2016; (d) Małopolska 2001-2016; Figure S12: Relation between daily maximum temperature and relative mortality risk (age 65 and older) in warm months (June-September) for towns with population of 10-25 thousand: (a) Wielkopolska 1989-1998; (b) Małopolska 1989-1998; (c) Wielkopolska 2001-2016; (d) Małopolska 2001-2016; Figure S13: Relation between daily maximum temperature and relative mortality risk (all non-accidental causes) in warm months (June-September) for towns with population of below 10 thousand: (a) Wielkopolska 1989-1998; (b) Małopolska 1989-1998; (c) Wielkopolska 2001-2016; (d) Małopolska 2001-2016; Figure S14: Relation between daily maximum temperature and relative mortality risk (cardiovascular diseases) in warm months (June-September) for towns with population of below 10 thousand: (a) Wielkopolska 1989-1998; (b) Małopolska 1989-1998; (c) Wielkopolska 2001-2016; (d) Małopolska 2001-2016; Figure S15: Relation between daily maximum temperature and 
relative mortality risk (age 65 and older) in warm months (June-September) for towns with population of below 10 thousand: (a) Wielkopolska 1989-1998; (b) Małopolska 1989-1998; (c) Wielkopolska 2001-2016; (d) Małopolska 2001-2016; Figure S16: Relation between daily maximum temperature and relative mortality risk (all non-accidental causes) in warm months (June-September) for villages: (a) Wielkopolska 1989-1998; (b) Małopolska 1989-1998; (c) Wielkopolska 2001-2016; (d) Małopolska 2001-2016; Figure S17: Relation between daily maximum temperature and relative mortality risk (cardiovascular diseases) in warm months (June-September) for villages: (a) Wielkopolska 19891998; (b) Małopolska 1989-1998; (c) Wielkopolska 2001-2016; (d) Małopolska 2001-2016; Figure S18: Relation between daily maximum temperature and relative mortality risk (age 65 and older) in warm months (June-September) for villages: (a) Wielkopolska 1989-1998; (b) Małopolska 1989-1998; (c) Wielkopolska 2001-2016; (d) Małopolska 2001-2016.

Author Contributions: Conceptualization, D.G.; methodology, D.G and I.P.; software, D.G and I.P.; validation, A.C.; formal analysis, D.G. and I.P.; writing-original draft preparation, D.G and A.C.; writing-review and editing, D.G, A.C and I.P.; visualization, D.G and I.P.; project administration, D.G.; funding acquisition, D.G. All authors have read and agreed to the published version of the manuscript.

Funding: This research was funded by National Science Centre of Poland (NCN), grant number 2017/01/X/HS4/01029.

Institutional Review Board Statement: Not applicable.

Informed Consent Statement: Not applicable.

Data Availability Statement: Not applicable.

Conflicts of Interest: The authors declare no conflict of interest.

\section{References}

1. Perkins, S.E.; Alexander, L.V.; Nairn, J.R. Increasing frequency, intensity and duration of observed global heatwaves and warm spells. Geophys. Res. Lett. 2012, 39, L20714. [CrossRef]

2. Perkins-Kirkpatrick, S.E.; Lewis, S.C. Increasing trends in regional heatwaves. Nat. Comm. 2020, 11, 3357. [CrossRef] [PubMed]

3. Della-Marta, P.M.; Haylock, M.R.; Luterbacher, J.; Wanner, H. Doubled length of western European summer heat waves since 1880. J. Geophys. Res. 2007, 112, D15103. [CrossRef]

4. Dunn, R.J.; Alexander, L.V.; Donat, M.G.; Zhang, X.; Bador, M.; Herold, N.; Lippmann, T.; Allan, R.; Aguilar, E.; Barry, A.A.; et al. Development of an updated global land in situ-based data set of temperature and precipitation extremes: HadEX3. J. Geophys. Res. Atmos. 2020, 125, e2019JD032263. [CrossRef]

5. Graczyk, D.; Pińskwar, I.; Kundzewicz, Z.W.; Hov, Ø.; Førland, E.J.; Szwed, M.; Choryński, A. The heat goes on-changes in indices of hot extremes in Poland. Theor. Appl. Climatol. 2017, 129, 459-471. [CrossRef]

6. Wibig, J. Has the frequency or intensity of hot weather events changed in Poland since 1950? Adv. Sci. Res. 2012, 8, 87-91. [CrossRef]

7. Wypych, A.; Sulikowska, A.; Ustrnul, Z.; Czekierda, D. Temporal Variability of Summer Temperature Extremes in Poland. Atmosphere 2017, 8, 51. [CrossRef]

8. Sulikowska, A.; Wypych, A. Seasonal Variability of Trends in Regional Hot and Warm Temperature Extremes in Europe. Atmosphere 2021, 12, 612. [CrossRef]

9. Añel, J.A.; Fernández-González, M.; Labandeira, X.; López-Otero, X.; De la Torre, L. Impact of Cold Waves and Heat Waves on the Energy Production Sector. Atmosphere 2017, 8, 209. [CrossRef]

10. De Bono, A.; Giuliani, G.; Kluser, S.; Peduzzi, P. Impacts of summer 2003 heat wave in Europe. Eur. Environ. Alert Bull. 2004, 2, $1-4$.

11. Robine, J.M.; Cheung, S.L.; Le Roy, S.; Van Oyen, H.; Herrmann, F.R. Report on Excess Mortality in Europe during Summer 2003. EU Community Action Programme for Public Health, Grant Agreement 2005114. 2007, p. 13. Available online: https: / / ec.europa.eu/health/ph_projects/2005/action1/docs/action1_2005_a2_15_en.pdf (accessed on 4 July 2021).

12. Munich Re. Natural Catastrophes 2010 Analyses, Assessments, Positions; Munich Re: Munich, Germany, 2011.

13. Graczyk, D.; Kundzewicz, Z.W.; Choryński, A.; Førland, E.J.; Pińskwar, I.; Szwed, M. Heat-related mortality during hot summers in Polish cities. Theor. Appl. Climatol. 2019, 136, 1259-1273. [CrossRef]

14. Root, C.J. Deaths during the heat wave of July, 1936 at Detroit. Bull. Am. Meteorol. Soc. 1937, 18, 232-236. [CrossRef]

15. Gover, M. Mortality during periods of excessive temperature. Public Health Rep. 1938, 53, 1122-1143. [CrossRef]

16. Kuchcik, M.; Degórski, M. Heat- and cold-related mortality in the north-east of Poland as an example of the socio-economic effects of extreme hydrometeorological events in the Polish Lowland. Geogr. Pol. 2009, 82, 69-78. [CrossRef] 
17. Kuchcik, M. Mortality and thermal environment (UTCI) in Poland-Long-term, multi-city study. Int. J. Biometeorol. 2021, 65, 1529-1541. [CrossRef]

18. Choryński, A.; Pińskwar, I.; Graczyk, D.; Krzyżaniak, M. The Emergence of Different Local Resilience Arrangements Regarding Extreme Weather Events in Small Municipalities-A Case Study from the Wielkopolska Region, Poland. Sustainability 2022, 14, 2052. [CrossRef]

19. Gabriel, K.; Endlicher, W. Urban and rural mortality rates during heat waves in Berlin and Brandenburg, Germany. Environ. Pollut. 2011, 159, 2044-2050. [CrossRef]

20. Urban, A.; Davídkovová, H.; Kyselý, J. Heat- and cold-stress effects on cardiovascular mortality and morbidity among urban and rural populations in the Czech Republic. Int. J. Biometeorol. 2013, 58, 1057-1068. [CrossRef]

21. Kenney, L.W.; Craighead, D.H.; Alexander, L.M. Heat waves, aging, and human cardiovascular health. Med. Sci. Sports Exerc. 2014, 46, 1891-1899. [CrossRef] [PubMed]

22. Yin, Q.; Wang, J. The association between consecutive days' heat wave and cardiovascular disease mortality in Beijing, China BMC Public Health 2017, 17, 223. [CrossRef]

23. Rodrigues, M.; Santana, P.; Rocha, A. Modelling of Temperature-Attributable Mortality among the Elderly in Lisbon Metropolitan Area, Portugal: A Contribution to Local Strategy for Effective Prevention Plans. J. Urban Health 2021, 98, 516-531. [CrossRef] [PubMed]

24. Rodrigues, M.; Santana, P.; Rocha, A. Modelling climate change impacts on attributable-related deaths and demographic changes in the largest metropolitan area in Portugal: A time-series analysis. Environ. Res. 2020, 190, 109998. [CrossRef]

25. Rodrigues, M.; Santana, P.; Rocha, A. Statistical Modelling of Temperature-Attributable Deaths in Portuguese Metropolitan Areas under Climate Change: Who Is at Risk? Atmosphere 2020, 11, 159. [CrossRef]

26. IMGW-PIB. Public Data Repository. Polish Institute of Meteorology and Water Management-National Research Institute. Available online: https:/ / dane.imgw.pl (accessed on 6 July 2017).

27. Barnett, A.G.; Tong, S.; Clements, A.C. What measure of temperature is the best predictor of mortality? Environ. Res. 2010, 110, 604-611. [CrossRef] [PubMed]

28. Gasparrini, A. Distributed Lag Linear and Non-Linear Models in R: The Package dlnm. J. Stat. Softw. 2011, 43, 1-20. [CrossRef] [PubMed]

29. Kobza, J.; Geremek, M. Exploring the Life Expectancy Increase in Poland in the Context of CVD Mortality Fall: The Risk Assessment Bottom-Up Approach, From Health Outcome to Policies. Inquiry 2015, 52, 1-12. [CrossRef]

30. Bustinza, R.; Lebel, G.; Gosselin, P.; Bélanger, D.; Chebana, F. Health impacts of the July 2010 heat wave in Québec, Canada. BMC Public Health 2013, 13, 56. [CrossRef]

31. Lan, L.; Cui, G.; Yang, C.; Wang, J.; Sui, C.; Xu, G.; Zhou, D.; Cheng, Y.; Guo, Y.; Li, T. Increased Mortality During the 2010 Heat Wave in Harbin, China. EcoHealth 2012, 9, 310-314. [CrossRef]

32. Azhar, G.S.; Mavalankar, D.; Nori-Sarma, A.; Rajiva, A.; Dutta, P.; Jaiswal, A.; Sheffield, P.; Knowlton, K.; Hess, J.J.; Ahmedabad HeatClimate Study Group. Heat-related mortality in India: Excess all-cause mortality associated with the 2010 Ahmedabad heat wave. PLoS ONE 2014, 9, e91831. [CrossRef]

33. Wibig, J. Heat waves in Poland in the period 1951-2015: Trends, patterns and driving factors. Meteorol. Hydrol. Water Manag. 2018, 6, 37-45. [CrossRef]

34. Tomczyk, A.M.; Bednorz, E.; Matzarakis, A. Human-biometeorological conditions during heat waves in Poland. Int. J. Climatol. 2020, 40, 5043-5055. [CrossRef]

35. Matzarakis, A.; Muthers, S.; Koch, E. Human biometeorological evaluation of heat-related mortality in Vienna. Theor. Appl. Climatol. 2011, 105, 1-10. [CrossRef]

36. Hajat, S.; Kovats, R.S.; Atkinson, R.W.; Haines, A. Impact of hot temperatures on death in London: A time series approach. J. Epidemiol. Community Health 2002, 56, 367-372. [CrossRef]

37. Braga, A.L.; Zanobetti, A.; Schwartz, J. The effect of weather on respiratory and cardiovascular deaths in 12 U.S. cities. Environ. Health Perspect. 2002, 110, 859-863. [CrossRef] [PubMed]

38. Tol, R.S.J. Estimates of the damage costs of climate change. Part 1: Benchmark estimates. Environ. Resour. Econ. 2002, 21, 47-73. [CrossRef]

39. Shi, L.; Kloog, I.; Zanobetti, A.; Liu, P.; Schwartz, J.D. Impacts of temperature and its variability on mortality in New England Nat. Clim. Change 2015, 5, 988-991. [CrossRef]

40. Stafoggia, M.; Forastiere, F.; Agostini, D.; Caranci, N.; De’Donato, F.; Demaria, M.; Michelozzi, P.; Miglio, R.; Rognoni, M.; Russo, A.; et al. Factors affecting in-hospital heat-related mortality: A multi-city case-crossover analysis. J. Epidemiol. Community Health 2008, 62, 209-215. [CrossRef]

41. Vandentorren, S.; Bretin, P.; Zeghnoun, A.; Mandereau-Bruno, L.; Croisier, A.; Cochet, C.; Ribéron, J.; Siberan, I.; Declercq, B.; Ledrans, M. Heat-related mortality. August 2003 heat wave in France: Risk factors for death of elderly people living at home. Eur. J. Public Health 2006, 16, 583-591. [CrossRef]

42. Ishigami, A.; Hajat, S.; Kovats, R.S.; Bisanti, L.; Rognoni, M.; Russo, A.; Paldy, A. An ecological time-series study of heat-related mortality in three European cities. Environ. Health 2008, 7, 5. [CrossRef]

43. Oudin Åström, D.; Åström, C.; Rekker, K.; Indermitte, E.; Orru, H. High summer temperatures and mortality in Estonia. PLoS ONE 2016, 11, e0155045. [CrossRef] 
44. Henderson, S.B.; Wan, V.; Kosatsky, T. Differences in heat-related mortality across four ecological regions with diverse urban, rural, and remote populations in British Columbia, Canada. Health Place 2013, 23, 48-53. [CrossRef] [PubMed]

45. Medina-Ramón, M.; Schwartz, J. Temperature, temperature extremes, and mortality: A study of acclimatisation and effect modification in 50 US cities. Occup. Environ. Med. 2007, 64, 827-833. [CrossRef] [PubMed]

46. Bakhsh, K.; Rauf, S.; Zulfiqar, F. Adaptation strategies for minimizing heat wave induced morbidity and its determinants. Sustain. Cities Soc. 2018, 41, 95-103. [CrossRef]

47. Stone, B., Jr.; Vargo, J.; Liu, P.; Habeeb, D.; DeLucia, A.; Trail, M.; Hu, Y.; Russell, A. Avoided Heat-Related Mortality through Climate Adaptation Strategies in Three US Cities. PLoS ONE 2014, 9, e100852. [CrossRef] 